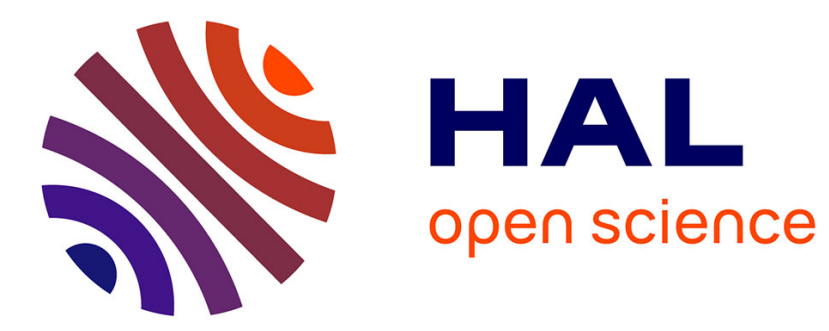

\title{
Melt inclusions at MT. Edixon (Antarctica): Chemistry, petrology and implications for the evolution of the Lanterman range
}

Fabio Ferri, Bernardo Cesare, Omar Bartoli, Silvio Ferrero, Rosaria Palmeri, Laurent Remusat, Stefano Poli

\section{To cite this version:}

Fabio Ferri, Bernardo Cesare, Omar Bartoli, Silvio Ferrero, Rosaria Palmeri, et al.. Melt inclusions at MT. Edixon (Antarctica): Chemistry, petrology and implications for the evolution of the Lanterman range. Lithos, 2020, 374-375, pp.105685. 10.1016/j.lithos.2020.105685 . hal-02959290

\section{HAL Id: hal-02959290 \\ https://hal.science/hal-02959290}

Submitted on 24 Dec 2020

HAL is a multi-disciplinary open access archive for the deposit and dissemination of scientific research documents, whether they are published or not. The documents may come from teaching and research institutions in France or abroad, or from public or private research centers.
L'archive ouverte pluridisciplinaire HAL, est destinée au dépôt et à la diffusion de documents scientifiques de niveau recherche, publiés ou non, émanant des établissements d'enseignement et de recherche français ou étrangers, des laboratoires publics ou privés. 


\section{MELT INCLUSIONS AT MT. EDIXON (ANTARCTICA):}

2 CHEMISTRY, PETROLOGY AND IMPLICATIONS FOR THE

3 EVOLUTION OF THE LANTERMAN RANGE

4

5

6

7
Fabio Ferri ${ }^{1}$, Bernardo Cesare ${ }^{1 *}$, Omar Bartoli $^{1}$, Silvio Ferrero ${ }^{2,3}$, Rosaria Palmeri ${ }^{4}$, Laurent Remusat ${ }^{5}$ and Stefano Poli ${ }^{6}$

${ }^{1}$ Department of Geosciences, University of Padua, Italy

${ }^{2}$ Institute of Earth and Environmental Science, University of Potsdam, Germany

${ }^{3}$ Museum für Naturkunde (MfN), Leibniz-Institut für Evolutions und

Biodiversitätsforschung, 10115 Berlin, Germany

${ }^{4}$ Museo Nazionale dell'Antartide, Sezione Scienze della Terra, Siena, Italy

${ }^{5}$ Institut de Mineralogie, Physique des Materiaux et Cosmochimie Museum National d'Histoire Naturelle, Paris, France

${ }^{6}$ Department of Earth Sciences, University of Milan, Italy

E-mail address: bernardo.cesare@unipd.it 
- Melt inclusions first discovered in peritectic garnets in paragneiss from the Edixon Metamorphic Complex, Lanterman Range, Antarctica

- Primary glasses from remelting of inclusions are sub-alkaline and peraluminous with 4-5 wt. $\% \mathrm{H}_{2} \mathrm{O}$ and $\mathrm{CO}_{2}<0.1$ wt. \%

- Anatexis at the Edixon Metamorphic Complex occurred at different crustal levels 

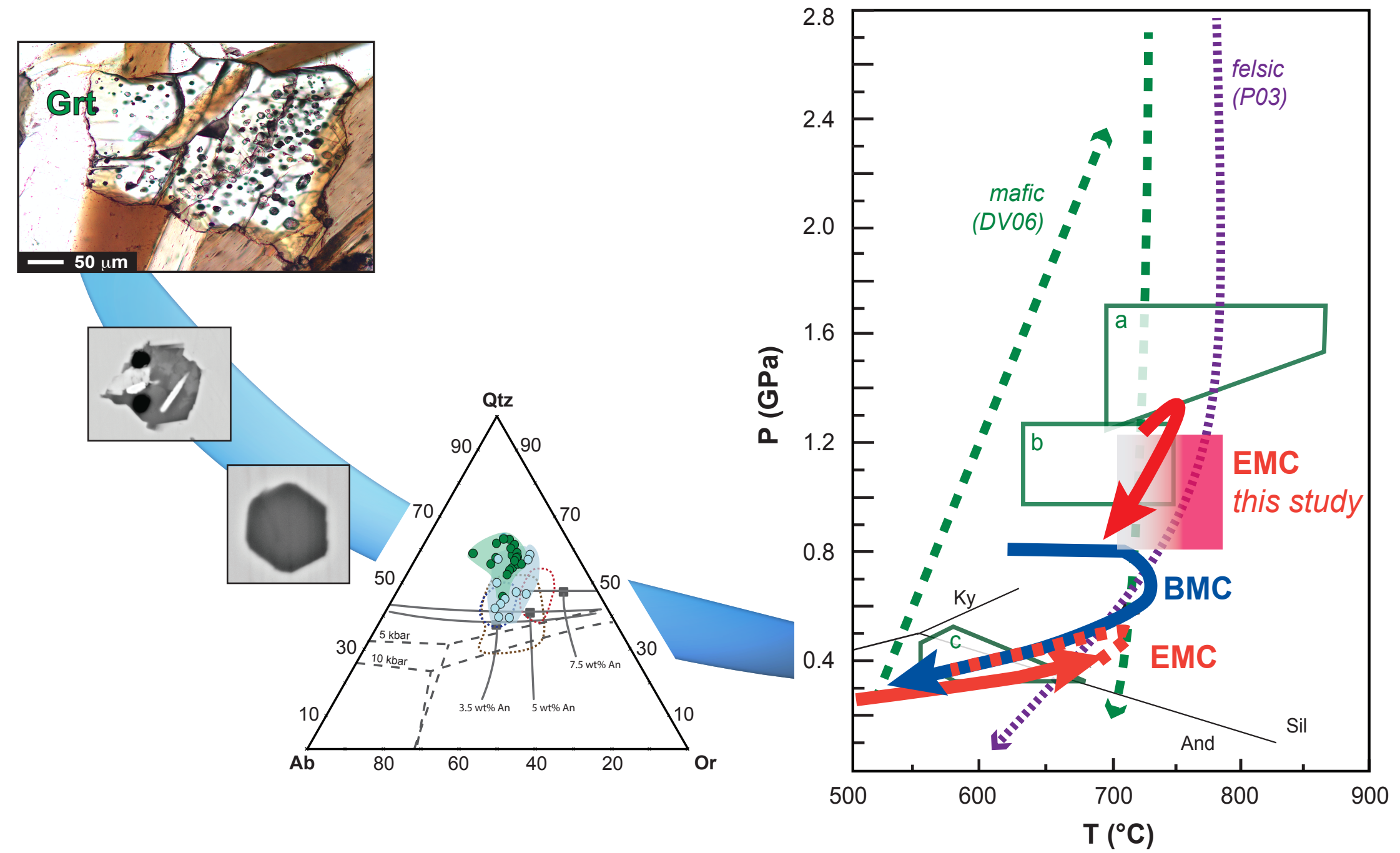


\section{ABSTRACT}

25 The recovery of melt inclusions in peritectic phases of metamorphic rocks brings the opportunity to retrieve the chemical composition of primary melts and infer melt entrapment

conditions. Here we report the first recovery of such inclusions in a medium-grade muscovitebiotite-plagioclase-K-feldspar-quartz gneiss from the Edixon Metamorphic Complex (EMC) of the Lanterman Range in Northern Victoria Land, Antarctica.

The most common inclusions are polycrystalline (PI) and fluid (FI) types coexisting in the same clusters and displaying frequent negative crystal shape and textures indicative of a primary origin. The PI contain muscovite + quartz $+\mathrm{H}_{2} \mathrm{O} \pm$ biotite \pm calcite \pm siderite \pm albite while the FI are composed by $\mathrm{CO}_{2}+\mathrm{H}_{2} \mathrm{O}+\mathrm{N}_{2}+\mathrm{CH}_{4} \pm \mathrm{H}_{2} \mathrm{~S}$. The PI were remelted in a piston cylinder apparatus at conditions of $740-900^{\circ} \mathrm{C}$ at $0.8-1.0 \mathrm{GPa}$ with complete remelting taking place at $760-780^{\circ} \mathrm{C}$. The remelted glass is sub-alkaline, peraluminous (ASI $\approx 1.3-1.5$ ) with $\mathrm{CaO} \approx 1.2-2.1 \mathrm{wt} \%$ and $\mathrm{K}_{2} \mathrm{O} \approx 3.4-4.1 \mathrm{wt} \%$, and contains $\approx 4.3-5.3 \mathrm{wt} \%$ of $\mathrm{H}_{2} \mathrm{O}$ and 400-1150 ppm of $\mathrm{CO}_{2}$.

The stable mineral assemblage is represented by muscovite + plagioclase + quartz $+\mathrm{K}-$

feldspar + garnet + melt \pm rutile coexisting with excess $\mathrm{C}-\mathrm{O}-\mathrm{H}$ fluid while biotite is retrograde (Ti 1.2 a.p.f.u.). The calculated phase equilibria and compositional isopleths in the MnCNKFMASHT model system delimit the equilibrium conditions to 1.0-1.3 GPa and 680$730^{\circ} \mathrm{C}$

Our study confirms that the EMC at the Lanterman Range is not a homogeneous metamorphic complex and that anatexis could have taken place at different crustal levels during the evolution of the Ross Orogen. Our results indeed suggest that, in the Lanterman Range, the high-pressure eclogitic rocks, the medium pressure amphibolite stage and the lowpressure amphibolite stage shared most of the late exhumation path. 
50 Key words: melt inclusions, crustal anatexis, nanogranitoids, Lanterman Range,

51 Edixon Metamorphic Complex

8

10

11

12

13

14

15

16

17

18

19

20

21

22

23

24

25

26

27

28

29

30

31

32

33

34

35

36

37

38

39

40

41

42

43

44

45

46

47

48

49

50

51

52

53

54

55

56

57

58

59

60

61

62

63

64

65 


\section{INTRODUCTION}

The discovery of primary melt inclusions (MI) hosted in peritectic minerals from high

grade metamorphic rocks has been described in recent papers (reviewed by Cesare et al., 2015 and Bartoli et al., 2016) and new examples are continuously adding from typical felsic crustal compositions or new mafic to ultramafic ones (Ferrero et al. 2018). The MI represent a window into the anatectic history of partially melted terranes (Acosta-Vigil et al., 2010) and may provide key microstructural and compositional information on crustal anatexis, like mechanisms and nature of the melting process, conditions of entrapment and melting, timeframes of melt production and segregation (Cesare et al., 2015). In the absence of any petrographical evidence of anatexis as pseudomorphs after melt films (Holness et al., 2011), the MI become a unique tool to infer past melting events throughout the metamorphic history of a rock. When MI coexist with fluid inclusions (FI), they are able to shed light on the fluid/melt/rock interactions during anatexis, and recent works demonstrated that melting processes are more commonly fluid-present than traditionally expected (Carvalho et al., 2018). The combination of MI and FI studies can also help understanding the exchange, transport and recycling of volatile species (especially $\mathrm{CO}_{2}$ ) in crustal evolution or during subduction.

In Antarctica, the presence of felsic-nanogranite inclusions produced after cooling of MI have been documented in garnets from the Lutzow-Holm Complex (East Antarctica, Hiroi et al., 2019). Here we report the first recovery of preserved MI in metapelitic garnets from the Edixon Metamorphic Complex from the Lanterman range in Antarctica. These inclusions turn out to be an essential tool to identify anatexis in rocks lacking further evidence of partial melting and, together with the petrological study of their host rocks, provide new clues to the geodynamic evolution of this crystalline basement. 


\section{SAMPLE DESCRIPTION}

\subsection{Geological setting}

The Ross orogenic belt is one of the Earth's great Phanerozoic mountain belts

resulting from convergence along the paleo-pacific margin of Antarctica in Gondwana land (Cawood, 2005; Talarico et al., 2004). The Northern Victoria Land (Fig. 1A, B) represents one of the major segments of the Ross orogenic belt (e.g., Federico et al., 2006, see summary by Stump, 1995) and comprises the Lanterman-Mariner suture (Ricci and Tessensohn, 2003, and references therein), a tectonic structure where peculiar HP-UHP metamorphic rocks have been reported (Ricci et al., 1996; Palmeri et al., 2011).

From east to west, the Northern Victoria Land can be divided into three contrasting tectonometamorphic terranes with NNW-SSE structural trends separated by major faults (Bradshaw and Laird, 1983): 1) the Robertson Bay Terrane, 2) the Bowers Terrane and 3) the Wilson Terrane (Fig. 1B). The Wilson Terrane represents the palaeo-Pacific margin of Gondwana in the region and consists of intermediate- to high-P metamorphic rocks with local eclogites close to the Lanterman-Mariner suture, (Grew et al., 1984; Di Vincenzo et al., 1997; Ricci et al., 1997), and of low-P metamorphic rocks (Palmeri et al., 1991) with local remnants of a polymetamorphic granulite complex (Talarico et al., 1995). The Wilson Terrane was extensively intruded by the Granite Harbour Intrusive Complex, an orogenic association of Cambro-Ordovician granitoids showing arc affinity (Bomparola et al., 2006; Kleinschmidt and Tessensohn, 1987; Borg et al., 1990; Ghezzo et al., 1989).

The Lanterman-Mariner suture separates the Wilson Terrane and the Bowers Terrane and is best exposed in two areas, namely the Lanterman Range to the north and the Mountaineer Range to the south. From west to east, three different lithotectonic units have been identified in the Lanterman Range area of the Lanterman-Mariner suture (Talarico et al., 1998): i) the Edixon Metamorphic Complex, ii) the Bernstein Metamorphic Complex and iii) 
101 the Gateway Hills Metamorphic Complex (Fig. 1C). The Edixon Metamorphic Complex

mainly consists of micaschists and gneisses containing bands and lenses of calc-silicate rocks, with minor amphibolites in the southernmost outcrops of the range. This complex underwent medium- to high-grade metamorphism and partial melting under low-P conditions and shows close similarities to the internal sequences of the Wilson Terrane, with the presence of migmatites and abundant granitoids of the Granite Harbour Intrusive Complex. The Bernstein Metamorphic Complex consists of micaschists and gneisses affected by medium- to highgrade metamorphism under intermediate-P conditions. In contrast to the Edixon Metamorphic Complex, calc-silicate rocks, migmatites and granitoids are rare (Ghiribelli, 2000; Talarico et al., 1998). The Gateway Hills Metamorphic Complex is characterized by abundant mafic and ultramafic rocks, including well-preserved eclogite-facies rocks, with minor gneisses and quartzites (Di Vincenzo et al., 1997; Ghiribelli et al., 2002; Palmeri et al., 2003, 2007, 2009, 2011). There are no granitoids in this complex (Talarico et al., 1998). Recently Di Vincenzo et al. (2016) established that two eclogite types coexist along the same ridge at the Lanterman Range: i) medium-grained,"colder" and undeformed eclogites, that recorded both prograde and peak conditions at nearly $530 \mathrm{Ma}(\mathrm{U}-\mathrm{Pb}$ zircon age) during ongoing regional calc-alkaline magmatism, and ii) finer-grained, "hotter" and slightly deformed eclogites, that recorded only metamorphic peak conditions at nearly $500 \mathrm{Ma}$ and hints of the subsequent retrogression $(\approx$ $480 \mathrm{Ma}$ ), coincident with the outboard accretion of an island arc (Bowers Terrane) onto the Gondwanan margin.

The evolution of the Lanterman Range (Capponi et al., 1999, 2002; Crispini et al., 2007; Di Vincenzo et al., 2014, 2016; Federico et al., 2010) can be summarized in a west123 over-east thrusting at ca. $500 \mathrm{Ma}$, followed by sinistral strike-slip shearing at 480-460 Ma 124 ago, both under amphibolite to greenschist-facies metamorphism. Large-amplitude folding of 
125 the late Ross or Lachlan orogens in the late Ordovician and Cenozoic brittle tectonics terminated the evolution of the suture.

\subsection{Petrography and bulk composition}

The studied rock belongs to the Edixon Metamorphic Complex of the Lanterman Range, was sampled at SE of Mt. Edixon (71 $\left.{ }^{\circ} 50^{\prime} 23.597^{\prime} \mathrm{S}, 163^{\circ} 39^{\prime} 41.35^{\prime \prime} \mathrm{E}\right)$ and stored in the PNRA (Programma Nazionale Ricerche in Antartide) rock repository at the Museo Nazionale dell'Antartide (Siena, Italy) as specimen 24-12-94GO5 (from hereafter GO5). The rock is a fine-grained psammitic gneiss composed of biotite, muscovite, garnet, quartz, plagioclase, $\mathrm{K}$-feldspar, minor ilmenite, apatite and tourmaline, and free of $\mathrm{Al}_{2} \mathrm{SiO}_{5}$ polymorphs (Fig. 2). Muscovite and biotite define the main foliation and show mm-sized crystals with no evidence of alteration. Quartz is abundant and occurs in coarse crystals or tiny aggregates of subgrains with segmented borders showing evidence of bulging. Garnet is scarce, with average diameter $<400 \mu \mathrm{m}$ and exceptionally up to $\approx 1 \mathrm{~mm}$. The sample displays evidence for extensive down-temperature replacement of garnet by biotite (Figure 2B, C).

Overall, the mineralogical composition and texture of the studied rock would suggest a medium grade metapsammite. Typical microstructural evidence of melt presence such as grains with euhedral crystal faces or pseudomorphs after melt films (e.g., Holness et al., 2011) are not present, and only the occurrence of melt inclusionsin garnet (Fig. 2B, C) attests for the former anatectic history of the rock.

\section{METHODS}

\subsection{Analytical techniques}

After MI recognition by optical microscopy, the mineral phases and the inclusions were first characterized in detail on polished thin sections by back-scattered electron images (BSEs) obtained with FESEM Sigma Zeiss at the ICMATE - CNR of Padova and with SEM 149 CamScan MX3000 at the Department of Geoscience of the University of Padova. 
The mineral phases and the glass of the inclusions were investigated by Micro-Raman

spectroscopy using the HORIBA Jobin Yvon LabRAM HR 800 located at the Institute of Earth and Environmental Science, University of Potsdam. The machine is equipped with a

Peltier-cooled multichannel CCD detector and coupled with an Olympus BX41 petrographic microscope. An air-cooled NdYAG laser was used for excitation $(\lambda=532 \mathrm{~nm}$, laser power on the sample of $2-3 \mathrm{~mW}$ ) with a grating of 300 lines $/ \mathrm{mm}$, slit width and confocal hole set to 100 and $200 \mu \mathrm{m}$, respectively. The Raman spectra of the solid and fluid phases were acquired with a $100 \times$ objective in the wavenumber range $100-4000 \mathrm{~cm}^{-1}$, integrating 3 repetitions of $60 \mathrm{~s}$ with spectral resolution of $10 \mathrm{~cm}^{-1}$.

The composition of mineral phases and glasses was determined using a Jeol JXA 8200 160 Superprobe at the Dipartimento di Scienze della Terra, Università di Milano (Italy) using 161 natural and synthetic silicates and oxides as standards. Analytical parameters for minerals 162 were $15 \mathrm{kV}$ accelerating voltage, $5 \mathrm{nA}$ current, counting time of $30 \mathrm{~s}$ on peak and $10 \mathrm{~s}$ on 163 background. For glass analyses, the beam diameter was reduced to $1 \mu \mathrm{m}$ and the counting 164 time to $10 \mathrm{~s}$ on peak and $2 \mathrm{~s}$ on background. Sodium, K, Al, and Si were the first analyzed 165 elements to limit element loss. Concentrations were corrected against leucogranitic glass 166 standards with comparable $\mathrm{H}_{2} \mathrm{O}$ contents (Morgan and London, 2005). Details concerning the 167 application of correction factors and the composition of the standard glasses are given by 168 Ferrero et al. (2012) and Bartoli et al. (2013a, 2013b).

171 Paris (France). Polished experimental capsules with MI exposed on the garnet surface and 172 standard glasses were mounted in Indium (Aubaud et al., 2007). MI were identified by 173 collecting secondary ion images of $\mathrm{Si}, \mathrm{K}$ and Fe. For every analysis, we first performed a pre174 sputtering step on a $3 \times 3 \mu \mathrm{m}^{2}$ surface area for 2 min with a $400 \mathrm{pA}$ primary $\mathrm{Cs}^{+}$beam to 
remove gold coating, surface contamination and reach a steady-state sputtering regime. Then

176 a primary beam of $37 \mathrm{pA}$ was used for data acquisition. Data were acquired by rastering a $3 \times$ $1773 \mu \mathrm{m}^{2}$ surface area and collecting only ions from the inner $1 \times 1 \mu \mathrm{m}^{2}$ (beam blanking mode) 178 to reduce surface contamination. Each analysis stacked about 200 cycles, each cycle being $1791.024 \mathrm{~s}$ long. The ${ }^{6} \mathrm{OH}^{-}$(used as a proxy for $\mathrm{H}_{2} \mathrm{O}$ ), ${ }^{28} \mathrm{Si}^{-},{ }^{39} \mathrm{~K}^{16} \mathrm{O}^{-}$and ${ }^{56} \mathrm{Fe}^{16} \mathrm{O}^{-}$were recorded 180 simultaneously in multicollection mode. We checked that ${ }^{16} \mathrm{OH}^{-} / 28 \mathrm{Si}^{-}$ratio was stable during 181 MI analyses (see Supplementary material). Secondary ions were collected by electron 182 multipliers with a dead time of $44 \mathrm{~ns}$. Mass resolution was set to 10000 . One inclusion was 183 large enough for replicated analyses. For NanoSIMS calibration we used a $5.5 \mathrm{wt} \% \mathrm{H}_{2} \mathrm{O}-$ 184 bearing leucogranitic glass from Acosta-Vigil et al. (2003), a $4.3 \mathrm{wt} \% \mathrm{H}_{2} \mathrm{O}$ - bearing 185 leucogranitic glass from Behrens and Jantos (2001) and an anhydrous leucogranitic glass 186 from Morgan and London (2005). The standards used for the determination of $\mathrm{CO}_{2}$ contents 187 were four trachyandesitic standards (STR 9, 10, 11 and 13) from the Stromboli volcano 188 experimentally doped in carbon and water by Bureau et al. (2003). H and C concentrations 189 were recalculated as $\mathrm{H}_{2} \mathrm{O}$ and $\mathrm{CO}_{2}$, respectively. Data corrections, using the aforementioned 190 calibration, and error calculations were performed using the $\mathrm{R}$ program following the 191 procedure described in Bartoli et al. (2014) and Thomen et al. (2014). During the session, the 192 vacuum in the analysis chamber remained between 2.5 and $5 \times 10^{-10}$ Torr.

\subsection{Mineral chemistry}

The mean compositions of minerals are reported in Table 1 (Supplementary Material). 195 Garnet is almandine-rich $(\approx 57 \mathrm{~mol} . \% \mathrm{Alm})$ with slight growth zoning. From core to rim, the 196 pyrope content decreases from 12 mol. \% to 8-10 mol. \% while grossular and spessartine 197 components increase from 2 mol. $\%$ to 4 mol. $\%$, and from $25 \mathrm{~mol}$. \% to $28-30 \mathrm{~mol}$. \% 198 respectively. The almandine content is constant throughout the crystal. 
The white mica is potassic $\left(\mathrm{X}_{\mathrm{Ms}}=0.92-0.95\right)$ with Si ranging from 3.00 to 3.04 a.p.f.u.

(11 oxygens), $\mathrm{Al}$ ranging from 2.76 to 2.72 a.p.f.u. and $\mathrm{X}_{\mathrm{Mg}}$ of $0.41-0.45$. The $\mathrm{TiO}_{2}$ content (0.03 a.p.f.u.) is typical of amphibolite-facies subsolidus muscovite (e.g., Cesare 1999, compare with Redler et al., 2011). The composition of the white mica is similar to that reported by Di Vincenzo et al. (2001) in sample BT5 and BT2 collected from the Edixon and Bernstein Metamorphic Complexes respectively and classified by the Authors as type-2 muscovite with selected area diffraction (SAED) pattern of 2M1 polytypes.

Biotite shows no systematic variations with microstructural occurrence, and has a 207 fairly constant composition, with Ti of 0.11-0.13 a.p.f.u. and $\mathrm{X}_{\mathrm{Mg}}$ of $0.44-0.45$. Also for 208 biotite the titanium content is typical of amphibolite-facies subsolidus conditions (Tajčmanová 209 et al., 2009. Plagioclase composition has 15-23 mol. \% anorthite, 76-84 mol.\% albite and ca. 1 210 mol.\% K-feldspar. Alkali feldspar is almost pure K-feldspar with albite <1-3 mol.\%.

\subsection{Remelting of inclusions}

The following nomenclature will be used: 'remelted' inclusions are those in which the crystalline assemblage was completely melted to a single glassy phase, but melt + vapor

homogenization was not achieved; 'rehomogenized' are those inclusions that appear as a homogeneous glass without bubbles (although former accidentally-trapped minerals may be present). Experimental remelting of the melt inclusions was performed on hand-picked separates of garnets obtained from crushed rock pieces sieved at $<500 \mu \mathrm{m}$ size. The garnet fragments were loaded into Au capsules filled with dry powder of silica or chemically pure $\mathrm{CaCO}_{3}$. The capsules were loaded in a salt $+\mathrm{MgO}+$ graphite assembly and experiments were performed in single stage piston cylinder apparatus at the Department of Geosciences of the University of Milan at condition from $740^{\circ} \mathrm{C}$ to $900^{\circ} \mathrm{C}$ at 0.8 and $1.0 \mathrm{GPa}$, with duration of 21-68 hours (Table 2). The temperature was controlled by a K-type thermocouple with 223 uncertainty of $\pm 5^{\circ} \mathrm{C}$. To avoid decrepitation of inclusions, quenching was performed at 
experimental pressure and load was released after achieving ambient temperature. After the experiments, the capsules containing garnet $+\mathrm{SiO}_{2}$ were mounted in epoxy and polished to expose rehomogenized inclusions, whereas the capsules containing garnet $+\mathrm{CaCO}_{3}$ were first opened and immersed in diluted $\mathrm{HCl}$ to dissolve calcite and recover the garnet grains. The garnet grains were mounted in epoxy and polished (more experimental details in Bartoli et al., 2013a and Ferrero et al., 2015).

\section{RESULTS}

\subsection{Microstructures of melt and fluid inclusions}

The inclusions preserved in the starting material and after experiments were characterized on the basis of optical microscopy BSE imaging, EDS elemental mapping and micro-Raman spectroscopy, and distinguished in fluid (FI), polycrystalline (PI) also called nanogranitoids (Cesare et al., 2015) and partially crystallized (= former melt, MI).

Inclusions have irregular distribution in some garnet hosts, but they tend to cluster at the rims of large crystals or in the core of tiny crystals (Fig. 2B, C). These microstructures are indicative of a primary entrapment (according to the classification of Roedder, 1984), and suggest that inclusions were mostly trapped during the final stage of garnet growth. The FI and PI coexist in the clusters suggesting that they belong to the same fluid inclusion assemblage and that entrapment took place during the same stage of garnet growth in a condition of fluid-melt immiscibility. Most FI and PI inclusions are $<10 \mu \mathrm{m}$ in diameter, with isometric (negative crystal) shapes, equally abundant and have comparable size range. In PI, typical phases are albite, K-feldspar, quartz, muscovite, biotite, calcite, siderite, rutile and 245 ilmenite. The FI contain a C-O-H fluid composed of $\mathrm{H}_{2} \mathrm{O}$ and $\mathrm{CO}_{2}$ (Fig. 3A). The presence of $246 \mathrm{H}_{2} \mathrm{O}$ is marked by the broad band between 3100 and $3600 \mathrm{~cm}^{-1}$, the $\mathrm{CO}_{2}$ by the presence of 
247 the Fermi diad (peaks at $1285 \mathrm{~cm}^{-1}$ and $1387 \mathrm{~cm}^{-1}$ ), with peak distance $(\Delta)$ corresponding to

$\mathrm{CO}_{2}$ density of $<0.1 \mathrm{~g} \mathrm{~cm}^{-1}$ (see Wang et al., 2011).

After the experiments, the inclusions were carefully inspected to infer the temperature of entrapment from approach to remelting equilibrium (Fig. 4). At $740^{\circ} \mathrm{C}$, the $\mathrm{MI}$ have well defined negative crystal shapes and contain glass (yellow arrows in Fig. 4) together with abundant unmelted crystals of quartz, biotite, muscovite, albite and ilmenite, indicating that remelting was incomplete (i.e., they are partially-remelted inclusions). At $760^{\circ} \mathrm{C}$, albite and muscovite are completely resorbed, biotite is less frequent, and quartz is still common with typical round shape, suggesting partial resorption. Few inclusions are completely remelted to a homogeneous glass with presence of a shrinkage bubble. At $780^{\circ} \mathrm{C}$ experiments show the best approach to equilibrium with $>40-50 \%$ remelted inclusions, displaying regular walls, negative crystal shape and absence of offshoots. The presence of resorbed quartz is rare. At $810^{\circ} \mathrm{C}$, completely or partly remelted inclusions display offshots (white arrows in Fig. 4) and the presence of secondary minerals (i.e., formed during experiments or upon quenching) as aggregates of tiny acicular Bt. Remelted inclusions represent $>70 \%$ of the total. At $850^{\circ} \mathrm{C}$ and $900^{\circ} \mathrm{C}$ almost all inclusions are remelted or rehomogenized but show evidence of overheating (see Cesare et al., 2015; Bartoli et al., 2013c; Acosta-Vigil et al., 2016) as indicated by i) presence of lobate-cuspate walls at the contact with the host garnet, ii) frequent offshoots, iii) growth of secondary garnet at the inclusion walls, iv) segmented straight walls after assimilation of the Grt (at $900^{\circ} \mathrm{C}$ ). Ilmenite and rutile as trapped phases become less common at $\mathrm{T}>810^{\circ} \mathrm{C}$ and almost absent at $900^{\circ} \mathrm{C}$. In the Raman spectrum shown in Figure $3 \mathrm{C}$, the remelted glass has a broad band at $\approx 3400 \mathrm{~cm}^{-1}$ related to the presence of $\mathrm{H}_{2} \mathrm{O}$, while 269 the shrinkage bubble within the glass contains a fluid mixture of $\mathrm{CO}_{2}+\mathrm{N}_{2}+\mathrm{CH}_{4}$ (Fig. 3B). 


\subsection{Major elements composition of remelted glasses}

In order to determine the composition of the melt produced during anatexis of the metapsammite, and to infer the temperature of entrapment of inclusions, we conducted EMP glass analyses on completely or partially remelted glasses to explore their potential interaction with the host garnet as function of experimental temperature (Table 3). We excluded analyses with clear signal of contamination either by minerals preserved in the inclusions or by host garnet e.g. $\mathrm{SiO}_{2}<60 \mathrm{wt} \%$ and $>80 \mathrm{wt} \%$, or $\mathrm{Al}_{2} \mathrm{O}_{3}>20 \mathrm{wt} \%$ or $\left(\mathrm{FeOt}+\mathrm{MgO}+\mathrm{TiO}_{2}\right)>7$ $\mathrm{wt} \%$. The difference to $100 \%$ of the totals may reflect not only the fluid content but also interaction of the microprobe beam with the shrinkage bubble if present below the polished surface of the MI (see discussion below on $\mathrm{H}_{2} \mathrm{O}-\mathrm{CO}_{2}$ content), so results of the analyses were recalculated on anhydrous basis $(100 \mathrm{wt} \%)$. Figure 5 compares the chemical composition of the glasses recovered in all the experiments. The average $\mathrm{MnO}$ vs. $\mathrm{FeO}_{\mathrm{t}}$ content is respectively $0.5 \mathrm{wt} \%$ and $1.6-1.7 \mathrm{wt} \%$ up to $780^{\circ} \mathrm{C}$, and systematically increases from $810^{\circ} \mathrm{C}$ to $900^{\circ} \mathrm{C}$. The $\mathrm{FeO}_{\mathrm{t}}+\mathrm{MgO}+\mathrm{TiO}_{2}$ is $1-3 \mathrm{wt} \%$ up to $780^{\circ} \mathrm{C}$ with $\mathrm{SiO}_{2}$ increasing from $66 \mathrm{wt} \%$ at $740^{\circ} \mathrm{C}$ to $72-76 \mathrm{wt} \%$ at $760^{\circ} \mathrm{C}$ and $75-79 \mathrm{wt} \%$ at $780^{\circ} \mathrm{C}$. At $\mathrm{T}>810^{\circ} \mathrm{C}$, the $\mathrm{FeO}_{\mathrm{t}}+\mathrm{MgO}+$ $285 \mathrm{TiO}_{2}$ is inversely proportional to $\mathrm{SiO}_{2}\left(\right.$ lower $\mathrm{SiO}_{2}$, higher $\left.\mathrm{FeO}_{\mathrm{t}}+\mathrm{MgO}+\mathrm{TiO}_{2}\right)$. The $\mathrm{CaO}$ vs. $286 \mathrm{SiO}_{2}$ has similar behavior for most temperatures with the $\mathrm{SiO}_{2}$ increasing from $760^{\circ} \mathrm{C}$ to $287780^{\circ} \mathrm{C}$ and decreasing from $780^{\circ} \mathrm{C}$ to $810^{\circ} \mathrm{C}, 850^{\circ} \mathrm{C}$ and $900^{\circ} \mathrm{C}$ (Fig. 5C). No temperature 288 dependence is visible on the $\mathrm{Na}_{2} \mathrm{O}$ vs. $\mathrm{SiO}_{2}$ plot, except at $900^{\circ} \mathrm{C}$ where the $\mathrm{SiO}_{2}$ is 289 systematically lower for comparable $\mathrm{Na}_{2} \mathrm{O}$ contents. The $\mathrm{Al}_{2} \mathrm{O}_{3}$ is inversely proportional to $290 \mathrm{SiO}_{2}$ at $760-810^{\circ} \mathrm{C}$ but values get dispersed at $\mathrm{T}>850^{\circ} \mathrm{C}$ resulting in an ASI number $>1$, with 291 the exception of few inclusions remelted at $850-900^{\circ} \mathrm{C}$. The systematic variations reported in 292 Fig. 5A-C and E may result from contamination of melt by mixtures of Grt-Qz and Feld-Qz 293 (see directions of exchange vectors reported in Fig. 5B and E) suggesting that host interaction 
294 is not negligible at $\mathrm{T}>810^{\circ} \mathrm{C}$. As a consequence, we consider the glass compositions obtained

at $760-780{ }^{\circ} \mathrm{C}$ as most representative of the anatectic melt trapped within garnets.

In Fig. 6 the composition of glasses remelted at $760-780^{\circ} \mathrm{C}$ is plotted on the pseudoternary normative diagrams Qz-Ab-Or and An-Ab-Or. Compositions at $760^{\circ} \mathrm{C}$ include remelted glasses with and without daughter quartz. The MI cluster above the cotectic lines at 0.5-1.0 GPa, which is consistent with the displacement of cotectic lines towards Qz apex as effect of increasing $\mathrm{Al}$ and $\mathrm{Ca}$ content in the granite model system (see Bartoli et al., 2016). The compostion of $\mathrm{MI}$ at $760^{\circ} \mathrm{C}$ differ by lower $\mathrm{SiO}_{2}$ which is related to the widespread presence of relict unmelted quartz in the inclusions. However, few glasses at $760^{\circ} \mathrm{C}$ overlap with glasses at $780^{\circ} \mathrm{C}$ suggesting that equilibrium melt composition are presumably achieved within the interval $760-780^{\circ} \mathrm{C}$ and represent the closest approximation to the original anatectic melt. Displacement of the MI composition from the minimum melt in the Qz-Ab-Or model system has been explained by Wilke et al. (2017) as due to the presence of extra components in natural systems, mostly $\mathrm{Ca}, \mathrm{Fe}$ and Ti. Wilke et al. (2017) report a displacement of the eutectic point to Or-enriched composition at similar Qz amount when melts have $\approx 3.5-7 \%$ normative An. Such An content corresponds to that of remelted glasses clustering at 2-7\% with few analyses up to $11-16 \%$. The MI show variation in the Qz/feldspar ratio as indicated by their distribution along the directories $\mathrm{Ab} / \mathrm{Or}=0.38$ and $\mathrm{Ab} / \mathrm{Or}=0.5$

312 collinear with the Qz apex. Such trends differ from those of Bartoli et al. (2016) who reported 313 compositional alignments of remelted granitic glasses parallel to the Qz-feldspar join and 314 interpreted them as due to slow diffusion of $\mathrm{Si}$ and $\mathrm{Al}$ compared to alkalis in granitic melts (Acosta-Vigil et al., 2006, 2017). In the An-Ab-Or projection, most glass compositions plot in 316 the granite field close to the boundary with Qz-monzonite, with few Qz-monzonite 317 compositions. Figure 6 also reports the composition of MI recovered in garnet of 318 metasediments from Ojén (Bartoli et al., 2013b, 2013c) and in plagioclase of Grt-Bt-Sil 
enclaves from El Hoyazo (Acosta-Vigil et al., 2010; Baroli et al., 2016) equilibrated at similar metamorphic conditions $\left(700^{\circ} \mathrm{C}\right.$ and $0.5 \mathrm{GPa}$ for Ojén, $700-750^{\circ} \mathrm{C}$ and $0.5-0.7 \mathrm{GPa}$ for El Hoyazo, see below). In terms of $\mathrm{Ab} / \mathrm{Or}$ ratio, the composition of glasses remelted at $760^{\circ} \mathrm{C}$ and $780^{\circ} \mathrm{C}$ are similar but those at $780^{\circ} \mathrm{C}$ have higher normative Qz and An. The glasses plot in the calcic field of the modified alkali-lime index $\left(\mathrm{MALI}=\mathrm{Na}_{2} \mathrm{O}+\mathrm{K}_{2} \mathrm{O}-\mathrm{CaO}\right)$ vs. $\mathrm{SiO}_{2}$ (wt\%) after Frost et al. (2001) and in the rhyolite field of the TAS classification (Fig. 7A, B).

\subsection{Volatile content of remelted glasses}

The $\mathrm{H}_{2} \mathrm{O}$ and $\mathrm{CO}_{2}$ concentration in glasses was determined by nanoSIMS only on MI remelted at $760^{\circ} \mathrm{C}$ and $780^{\circ} \mathrm{C}$ (Table 4 - Supplementary Material) and performed on selected homogeneous portion of the glass exposed on the surface of polished garnets.

The $\mathrm{H}_{2} \mathrm{O}$ content of individual analyses is reported in Fig. 8 and is between 2.2-8.0 wt $\%$ at $760^{\circ} \mathrm{C}$ and $3.0-6.5 \mathrm{wt} \%$ at $780^{\circ}$, while the corresponding $\mathrm{CO}_{2}$ is $250-850 \mathrm{ppm}$ at $760^{\circ} \mathrm{C}$ and $500-2200 \mathrm{ppm}$ at $780^{\circ} \mathrm{C}$. In Fig. $8 \mathrm{~B}$ and $\mathrm{C}$ the MI analyses are grouped according to host Grt and display similar variability except for garnets ANT9-1 and ANT8-1 displaying higher scatter for $\mathrm{H}_{2} \mathrm{O}$ and $\mathrm{CO}_{2}$, respectively. The averages at $760^{\circ} \mathrm{C}$ and $780^{\circ} \mathrm{C}$ (white circles in Fig. 8B, C) are similar for $\mathrm{H}_{2} \mathrm{O}$ with $4.3 \pm 1.7 \mathrm{wt} \%$ at $760^{\circ} \mathrm{C}$, and $5.3 \pm 1.0 \mathrm{wt} \%$ at $780^{\circ} \mathrm{C}$, and slightly differ for $\mathrm{CO}_{2}$ with $407 \pm 184 \mathrm{ppm}$ at $760^{\circ} \mathrm{C}$, and $1147 \pm 519 \mathrm{ppm}$ at $780^{\circ} \mathrm{C}$. In Figure $3 \mathrm{C}$ the measured $\mathrm{H}_{2} \mathrm{O}$ in remelted glasses is compared with maximum and minimum water contents expected in model primary granitic melts (Holtz et al., 2001) and will be discussed below. The Fig. 3D compares the $\mathrm{H}_{2} \mathrm{O}$ contents with the values predicted for $\mathrm{H}_{2} \mathrm{O}-$ undersaturated haplogranitic melts (Holtz et al., 2001) while the solidus is from thermodynamic modelling (see below).

\subsection{Thermodynamic modelling}

Constraints on the P-T conditions of melting and inclusions entrapment were obtained 343 by phase equilibria modelling (Fig. 9). Calculations were done in the model chemical system 
MnNCaKFMASHT using the Perple_X software (Connolly, 2009) with the thermodynamic

database of Holland and Powell (2003 revision). We used the solution models of White et al. (2007) for melt, Holland and Powell (1998) for garnet, Tajčmanová et al. (2009) for biotite,

Coggon and Holland (2002) for white mica, Newton et al. (1980) for plagioclase, and

Thompson and Hovis (1979) for K-feldspar. The bulk rock composition of the rock was obtained from XRF analysis and is reported as inset in Fig. 9. The bulk composition has no residual character and is considered representative of the original protolith with no necessity of melt reintegration (see Bartoli, 2017) because i) melt inclusions are the only petrographic evidence of anatexis (absence of melt pseudomorphs), ii) the composition of white mica, and that of biotite as well, is comparable to that of primary muscovite from amphibolite-facies subsolidus metapelites in the area (Di Vincenzo et al., 2001). The amount of $\mathrm{H}_{2} \mathrm{O}$ used in the calculation was assumed to be the L.O.I. (loss of ignition) from the XRF analysis $(=1.5 \mathrm{wt} \%)$. The presence of $\mathrm{CO}_{2}+\mathrm{H}_{2} \mathrm{O} \pm$ carbonates (calcite and siderite) in $\mathrm{PI}$ and FI point to a C-O-H fluid coexisting with the rock and melt during anatexis (Connolly and Cesare, 1993). Slight variations in $\mathrm{H}_{2} \mathrm{O}$ activity (tested from 0.8 to 1.0 but not reported here) resulted in limited displacement of the solidus at $\mathrm{P}>0.5 \mathrm{GPa}$, where the reaction slope is high and positive (see later and Fig. 9).

The petrographic study shows that the stable mineral assemblage is represented by Ms $+\mathrm{Pl}+\mathrm{Kf}+\mathrm{Grt}+\mathrm{Qz}+\mathrm{Liq} \pm \mathrm{Rt}$ coexisting with excess $\mathrm{C}-\mathrm{O}-\mathrm{H}$ fluid as indicated by the presence of FI and PI within the same cluster. In the pseudosection of Fig. 9, such assemblage is stable at $\mathrm{P}>0.5 \mathrm{GPa}$ within a triangular field limited by the fluid-present solidus curve and by the Ms-out/Als-in curve to temperatures of $690^{\circ} \mathrm{C}<\mathrm{T}<820^{\circ} \mathrm{C}$. The Fig. 10 (Supplementary Material) reports the calculated compositional isopleths for garnet, plagioclase and biotite. In larger garnets from cores to rims, the $\mathrm{X}_{\mathrm{Pyp}}$ slightly increases and $\mathrm{X}_{\text {Sps }}$ slightly decreases suggesting $\mathrm{a} \approx 50^{\circ} \mathrm{C}$ temperature increase during the garnet growth, 
while smaller garnets are homogeneous with composition similar to that of large garnet rims.

The $\mathrm{X}_{\mathrm{Alm}}$ in garnet has a slightly reversed tendency (higher temperature in the core and lower at the rim). The combination of garnet isopleths with the $\mathrm{X}_{\mathrm{An}}$ in plagioclase, delimit a P-T space corresponding to approximately $680^{\circ} \mathrm{C}$ to $730^{\circ} \mathrm{C}$ at $1.0-1.3 \mathrm{GPa}$ (Fig. 9). The low Ti content in biotite (0.12 a.p.f.u.) is not compatible with such temperatures and supports the petrographic observation of post peak recrystallization of biotite at $\mathrm{T}<600^{\circ} \mathrm{C}$.

The calculated isomodes for the phases biotite, garnet and melt reported in Fig. 9B and muscovite (nor reported for clarity) indicate that biotite and muscovite are partially consumed while limited amount of garnet is formed during progressive metamorphism at P-T evolving from condition 1 to conditions 2 in Fig. 9. Modelled muscovite decreases from 12 to $8 \mathrm{wt} \%$, biotite from 22 to $20 \mathrm{wt} \%$ and garnet increases from $1.5 \%$ to $2-4 \mathrm{wt} \%$. The melt produced is limited to $2-4 \mathrm{wt} \%$. The calculated isomodes are in agreement with the modal phase proportions constrained by mass balance calculation and corresponding to $7.9 \mathrm{wt} \%$ of muscovite, $28.1 \mathrm{wt} \%$ of biotite, $3.4 \mathrm{wt} \%$ of garnet and $\approx 2 \mathrm{wt} \%$ of melt.

\section{DISCUSSION}

\subsection{Conditions of MI entrapment}

The present study is an example of successful remelting of inclusions that adds to previous case studies of metasedimentary rocks undergoing anatexis (e.g., Cesare et al, 2015; Bartoli et al., 2016; Tacchetto et al., 2019; Carvalho et al., 2018). Previous works report MI entrapped under fluid present (Bartoli et al., 2013b) or fluid-absent melting of felsic (e.g., Cesare et al., 2015) or ultramafic rocks (Ferrero et al., 2018), and in a range of temperatures from upper-amphibolite to UHT conditions. The present case study yields new data on the onset of low-T anatexis of metasedimentary crust under possibly fluid-present conditions, which are likely to be more common than previously thought (see Carvalho et al., 2018 and discussion therein). 
The P-T-fluid conditions of melt entrapment within the host mineral can be

reconstructed combining the microstructures produced during remelting experiments at increasing temperature with the proportion of remelted inclusions, the compositional variation of major elements in glass and the thermodynamic modelling. In remelting experiments, microstructural changes include i) type of minerals coexisting with glass (daughter minerals and/or trapped phases), ii) presence of offshoots (suggesting decrepitation), iii) presence of irregular boundaries between MI and Grt (indicative of host interaction), iv) crystallization of new phases (indicative overheating), v) appearance of zoning/growth structures (indicative of intense host interaction). Since glasses remelted at $780^{\circ}$ are mostly free of daughter minerals, have no visible cracks/offshoots, and display limited or no chemical interaction with the host garnet (e.g., low $\mathrm{MnO}+\mathrm{FeO}_{\mathrm{t}}$ in Fig. 5), they can be confidently interpreted as representative of entrapment conditions. However, at $760^{\circ} \mathrm{C}$, where most inclusions have quartz which has not been re-homogenized and hence lower $\mathrm{SiO}_{2}$, few remelted inclusions resemble in texture and composition those typically recovered at $780^{\circ} \mathrm{C}$. One may question about the effect of kinetics on remelting conditions and the counter play of temperature and run duration on the achievement of equilibrium for remelting. Preliminary experiments at $780^{\circ} \mathrm{C}$ performed at different durations (hours to days, unpublished data) seem to confirm that run duration has an effect on remelting and that the chemical signature of the glasses recovered at lower experimental duration partly overlaps (though not completely) with the composition of 413 homogeneous glasses recovered at $760^{\circ} \mathrm{C}$. Even though the kinetics dilemma is out of the 414 scope of this work, it is reasonable to consider the interval $760-780^{\circ} \mathrm{C}$ at $0.8-1.0 \mathrm{GPa}$ as 415 representative of the entrapment conditions. Temperatures above $810^{\circ} \mathrm{C}$ are not representative 416 due to evident and intense glass-host interaction. Thermodynamic calculations indicate that 417 the wet solidus of the rock locates at $\approx 690-710^{\circ} \mathrm{C}$ between $0.5 \mathrm{GPa}$ and $1.5 \mathrm{GPa}$, and that the 418 stability field of the assemblage $\mathrm{Ms}+\mathrm{Pl}+\mathrm{Kf}+\mathrm{Grt}+\mathrm{Qz}+\mathrm{Liq} \pm \mathrm{Rt}$ is between $700-780^{\circ} \mathrm{C}$. 
The temperature intervals indicated by compositional isopleths of Grt and $\mathrm{Pl}$ and the mineral isomodes (Fig. 9) are more consistent with $\approx 700-730^{\circ} \mathrm{C}$ and $\approx 730-760^{\circ} \mathrm{C}$ respectively. The discrepancy between calculated and experimental conditions is maximum $60-80^{\circ} \mathrm{C}$ and can be ascribed to diverse sources of uncertainty in phase equilibria calculations, such as the quality of thermodynamic data and, in turn, the quality of mineral and melt solution models (White et al., 2011). For example, the current melt model requires improvements to reproduce properly natural processes (see discussion in Bartoli et al., 2013b), as already pointed out in previous works (e.g., Bartoli et al., 2013a and 2016; Grant, 2009 and White et al., 2011).

\subsection{Fluid regime and volatile content of the primary melt}

There are few lines of evidence suggesting that partial melting of the investigated rocks occurred in the presence of a fluid phase, including i) the coexistence of primary FI and PI within the same cluster, and ii) the major element composition of primary melt.

The abundant FI coexisting with PI in the same cluster indicate the presence of a C-O$\mathrm{H}$ fluid dominated by $\mathrm{H}_{2} \mathrm{O}$ and $\mathrm{CO}_{2}$. Graphite was not observed within the FI but carbonates (calcite and siderite) are common within garnets. Recently Carvalho et al. (2018) discussed the recovery of C-O-H bearing FI in metasedimentary rocks from Ivrea at amphibolite to granulite conditions and argued that "a (graphitic) rock undergoing melting will always show the presence of a free $\mathrm{C}-\mathrm{O}-\mathrm{H}$ fluid, in variable amounts and with variable $\mathrm{a}_{\mathrm{H} 2 \mathrm{O}}$ depending on pressure, temperature and the bulk composition of the system". According to Carvalho et al. (2018), the fluid regime during anatexis might be characterized by $\mathrm{CO}_{2}$-dominated fluid in processes dominated by dehydration of $\mathrm{OH}$-bearing phases. In the Edixon Complex, where the fluid was likely $\mathrm{H}_{2} \mathrm{O}$ dominated, conditions of entrapment are compatible with the 441 beginning of partial melting and potentially with both muscovite and biotite fluid-present 442 conditions. The calculated isomodes suggest that muscovite and biotite are consumed at the 443 solidus to produce limited amounts of melt and peritectic garnet, always in the absence of 
aluminum silicate. Since the muscovite fluid-present melting (without biotite) would produce

peritectic aluminum silicate instead of garnet (Weinberg and Hasalova, 2015), the rock assemblage is more consistent with a muscovite + biotite fluid-present melting reaction (Weinberg and Hasalova, 2015). Increasing a 1988; Gardien et al., 2000), but the experiments of Alonso-Perez et al. (2009) on Si-rich melts indicated the opposite, i.e. that stability of peritectic garnet increases with increasing $\mathrm{H}_{2} \mathrm{O}$ in melt.

The $\mathrm{H}_{2} \mathrm{O}$ content of glasses at $760^{\circ} \mathrm{C}$ is more scattered $(\approx 2-8 \mathrm{wt} \%)$ than at $780^{\circ} \mathrm{C}(\approx 4-$ $7 \mathrm{wt} \%$ ) but in both cases it is close to the values predicted for $\mathrm{H}_{2} \mathrm{O}$ saturation at $0.8 \mathrm{GPa}$ for haplogranitic melts $\left(\approx 7.6 \mathrm{wt} \%\right.$; Holtz et al., 2001, Fig. 8D). The lower $\mathrm{H}_{2} \mathrm{O}$ contents of some glasses may be explained as effect of heterogeneous distribution of the fluid (see discussion in Bartoli et al., 2014) and/or by the presence of a diluting carbonic species in the $\mathrm{COH}$ fluid, namely $\mathrm{CO}_{2}$. The $\mathrm{H}_{2} \mathrm{O}$ content of glasses determined as difference to 100 from EMPA analyses may yield similar contents, though Acosta-Vigil et al. (2016) report deviations up to $30 \%$. In Table 3, the average difference to 100 total decreases with increasing experimental temperatures from $\approx 14 \mathrm{wt} \%$ at $740^{\circ} \mathrm{C}$ to $\approx 12-11 \mathrm{wt} \%$ at $760-780^{\circ} \mathrm{C}$ and $\approx 10 \mathrm{wt} \%$ at 810 $900^{\circ} \mathrm{C}$. All values overestimate the measured $\mathrm{H}_{2} \mathrm{O}$ in glasses. Possible explanations may account for the presence of light and incompatible elements as B, which is abundant in first anatectic products or micropores and would be consistent with the presence of tourmaline in the rock. Concerning other volatiles, the $\mathrm{Cl}$ and $\mathrm{F}$ content of the glasses was below the detection limits (Table 3). This inconsistency requires further investigation.

The maximum $\mathrm{CO}_{2}$ content of the remelted glasses from NanoSIMS (with all $\mathrm{C}$ calculated as $\mathrm{CO}_{2}$ ) is $200-500 \mathrm{ppm}$ at $760^{\circ} \mathrm{C}$ and $500-2000 \mathrm{ppm}$ at $780^{\circ} \mathrm{C}$ (Fig. $8 \mathrm{~A}$ ). Such difference may be explained considering that i) the $\mathrm{CO}_{2}$ solubility in felsic melts slightly increases with increasing $\mathrm{T}$ at least at $0.5 \mathrm{GPa}$ (Tamic et al., 2001), ii) the $\mathrm{CO}_{2}$ solubility and 
speciation are affected by the glass composition, with total $\mathrm{CO}_{2}$ increasing with increasing $\mathrm{SiO}_{2}$ and decreasing with increasing $\mathrm{Na}_{2} \mathrm{O}$, and molecular $\mathrm{CO}_{2}$ prevailing on the $\left(\mathrm{CO}_{3}\right)^{2-}$ species in $\mathrm{SiO}_{2}$ rich- and $\mathrm{Na}_{2} \mathrm{O}$ poor- compositions (Brooker et al., 1999). At $780^{\circ} \mathrm{C}$, glasses have higher $\mathrm{SiO}_{2}-\mathrm{CaO}$ and lower $\mathrm{Na}_{2} \mathrm{O}$ with respect to glasses produced at $760^{\circ} \mathrm{C}$, so the $\mathrm{CO}_{2}$ speciation is expected to be dominated by molecular $\mathrm{CO}_{2}$. Even though most of the analyzed MI appeared homogeneous and bubble-free on polished surface, the presence of shrinkage bubbles deep within the inclusion cannot be excluded. Since the fluid phase preserved in the shrinkage bubble is mostly $\mathrm{CO}_{2}$-rich (Fig. 3B) in agreement with Wallace et al. (2015), this may account for an additional $\mathrm{CO}_{2}$ reservoir. If (slightly) higher resorption of the shrinkage bubbles takes place at increasing temperature, this may explain the higher $\mathrm{CO}_{2}$ content of glasses remelted at $780^{\circ} \mathrm{C}$ vs. $760^{\circ} \mathrm{C}$.

Granitic melt produced by water-present melting of metasedimentary rocks are expected to have higher ASI values than those produced by muscovite or biotite dehydration melting (Acosta-Vigil et al., 2003), to be enriched in $\mathrm{Na}_{2} \mathrm{O}$ and $\mathrm{CaO}$ (Weinberg and Hasalova, 2015), and to contain higher proportion of $\mathrm{MgO}$ and $\mathrm{FeO}$ at increasing water content or water activity (e.g. Conrad et al., 1988; Holtz and Johannes, 1991) at constant P-T (Patiño Douce and Beard, 1996). This is partly consistent with the glass composition at $780^{\circ} \mathrm{C}$, with ASI value of $1.57, \mathrm{MALI}\left(=\mathrm{Na}_{2} \mathrm{O}+\mathrm{K}_{2} \mathrm{O}-\mathrm{CaO}\right)$ value of $\approx 4.0 \pm 1.0 \mathrm{wt} \%, \mathrm{CaO}$ content of $\approx 1.27$ \pm 0.7 wt. $\%$ and $\mathrm{FeO}_{\text {tot }}+\mathrm{MgO}>2.1 \mathrm{wt} \%$, supporting the hypothesis of water-saturated partial melting.

\subsection{Anatexis and evolution of the Edixon Metamorphic Complex}

The tectonometamorphic history of the Edixon Metamorphic Complex and its role in the evolution of the Wilson Terrane has been primarily constrained by investigations along the western Lanterman Range but also southward within a wider belt including Salamander Range and Niagara Icefalls-Mountaineer Range regions which are exposed, as the Lanterman 
Range, close to the Wilson-Bowers tectonic boundary (e.g., Ghiribelli, 2000; Talarico et al.,

1998; 2004). In general, the EMC contains no record of an early HP metamorphic stage, but preserves a broad metamorphic zonation from low/medium grade to high grade up to anatexis.

However, previous studies showed the presence of rocks with contrasting P-T paths in different localities of the EMC (Castelli et al., 2003; Ghiribelli, 2000; Talarico et al., 1998, 2004). Ghiribelli (2000) recognized, at the western Lanterman Range and at the Salamander Range, that the rocks of the EMC show close similarities in lithological assemblages and metamorphic field gradients with other metasedimentary sequences characterized by an andalusite-sillimanite prograde counterclockwise path with isobaric cooling, and abundant Grt-Crd migmatites outcropping at the Deep Freeze Range (Palmeri et al. 1991, 1994; Palmeri, 1997). The latter low-pressure belt (> $200 \mathrm{~km}$ wide) located in an internal position of the Wilson Terrane is characterized by the presence of the Granite Harbor Intrusive complex (Borg et al., 1990; Ghezzo et al., 1989). The extensive and prolonged magmatic underplating of the Granite Harbor Intrusives bodies in the Wilson Terrane (from 520-530 to $500 \mathrm{Ma}$, Giacomini et al., 2007; Rocchi et al., 2004) possibly triggered, in different times, the anatectic event and, at the same time, promoted the juxtaposition of migmatites with contrasting P-T paths likely formed during the same Ross orogenic cycle (Palmeri, 1997).

In other localities, as at the Mountaineer Range region, a different P-T path has been proposed (Castelli et al., 2003; Talarico et al., 1998), involving an early decompression path following a moderate thickening, magmatic intrusions between 500 to $480 \mathrm{Ma}$ (the Granite Harbour intrusives), and a final cooling-unloading path has been inferred (Castelli et al., 2003).

In this paper, the MI preserved in peritectic garnet and phase equilibria modelling 517 demonstrate that the portion of the EMC close to Mt. Edixon experienced anatexis above $700^{\circ} \mathrm{C}$ and up to $760-780^{\circ} \mathrm{C}$ at $\approx 1.0 \mathrm{GPa}$, corresponding to the P-T conditions of entrapment. 
In the NW part of the Lanterman Range (Carnes Crag) Grt-Crd migmatites yield T-P

conditions at $\approx 700^{\circ} \mathrm{C}$ and $\approx 0.5 \mathrm{GPa}$ (Ghiribelli, 2000). Different conditions, however, were found in the southern portion of the EMC (Mountaineer Range), where the highest metamorphic grade shows temperature at $\approx 700-750^{\circ} \mathrm{C}$ and pressure from $\approx 0.5$ up to $0.6 \mathrm{GPa}$ (Castelli et al., 2003). The spread in low to medium pressure rock types and contrasting P-T paths at the boundary with the Wilson-Bowers terranes is not uncommon (Ricci et al., 1997; Ricci and Tessensohn, 2003), and supports the interpretation that anatexis could have taken place at different crustal levels during the evolution of the tectono-metamorphic stages of the Ross Orogen.

The latter is in keeping with the multiple and diachronous generations of white micas evidenced by Di Vincenzo et al., (2001) in the different metamorphic complexes of the Lanterman Range. The different white micas have been interpreted as testifying different P-T deformation stages developed during the evolution of the three metamorphic complexes (Di Vincenzo et al., 2001).

The white micas in the investigated sample GO5 have no evidence of retrogression, they are texturally and compositionally similar to type-2 white mica of Di Vincenzo et al., (2001), in fact they grow along the main amphibolite-facies foliation, and show a light enrichment in celadonitic component $(\mathrm{Si}=3.1$ a.p.f.u. and $\mathrm{Ti}=0.022$ a.p.f.u.). Moreover, data collected in this paper indicate that white micas are compatible with fluid-present melting as reconstructed by combination of thermodynamic modelling and MI remelting experiments. Since the composition of white micas in the Wilson Terrane evolves with time and the type-2 mica dates to ca. 480-490 Ma, we infer that the latter age could be referred to melting in the $541 \quad$ Lanterman Range.

Even though it is not possible to reconstruct a proper P-T-relative time path based on 543 the single sample GO5, the equilibrium conditions reconstructed from the remelting 
544 experiments and thermodynamic modelling allow extending the evolution of the EMC up to

ca. $\approx 1.0 \mathrm{GPa}$ at $760-780^{\circ} \mathrm{C}$. The latter data suggest two possibility: i) the EMC at the Lanterman Range is not an homogeneous metamorphic complex characterized by a lowpressure metamorphic imprint as postulated previously (Ghiribelli, 2000) but, similar to the HP-UHP belt (GHMC), it represents a mélange of different crustal slices; ii) the outcrop, from which the study sample comes from could be the extension towards the southern Lanterman Range of the intermediate-pressure belt of the BMC. Whatever the solution of the latter problem is, combining (Fig.10) geochronological data collected at the Lanterman Range (Di Vincenzo et al., 2016 and references therein), previous P-T paths (Di Vincenzo et al., 2001; Ghiribelli 2000; Talarico et al., 2004) and the results for sample GO5, the docking between the BMC and/or the different tectonic slices of the EMC might have been before 480 Ma. The latter age is widespread in the area and it was interpreted as the Early Ordovician final "closure" of micas at the Lanterman Range (Di Vincenzo et al., 2001) and mainly referred to the exhumation process of the different complexes, whereas in the inner Wilson Terrane that age correspond to the youngest undeformed calc-alkaline granitoids.

Thus, in the Lanterman Range, the high-pressure eclogitic rocks (GHMC), the medium pressure amphibolite stage (BMC/EMC pro parte) and the low-pressure amphibolite stage (EMC pro parte) shared most of the late exhumation path.

\section{AKNOWLEDGEMENTS}

This work was funded by the CaRiPaRo project Makearth (Cassa di Risparmio di

564 Padova e Rovigo) to FF, the grant SIR RBSI14Y7PF (Italian Ministry of Education, 565 University, Research) to OB, the PNRA (PdR 13/B2.07) to RP and by the German Federal 566 Ministry for Education and Research and the Deutsche Forschungsgemeinschaft (Project FE 567 1527/2-1 and FE 1527/2-2) to SF. 
Rock sample used in this study was collected by Gianni Capponi e Giacomo Oggiano

and is available at the PNRA (Programma Nazionale Ricerche in Antartide) rock repository located at the Museo Nazionale dell'Antartide (Siena, Italy).

\section{REFERENCES}

572 Acosta-Vigil, A., London, D., Morgan, G. B., VI, Dewers, T. A. (2003). Solubility of 573 excess alumina in hydrous granitic melts in equilibrium with peraluminous minerals at 700 $574800^{\circ} \mathrm{C}$ and $200 \mathrm{MPa}$, and applications of the aluminum saturation index. Contributions to 575 Mineralogy and Petrology, 146, 100-119.

Acosta-Vigil, A., London, D., Morgan, G.B. VI (2006). Experiments on the kinetics of partial melting of a leucogranite at $200 \mathrm{MPa} \mathrm{H} 2 \mathrm{O}$ and $690-800^{\circ} \mathrm{C}$ : Compositional variability of melts during the onset of $\mathrm{H} 2 \mathrm{O}$-saturated crustal anatexis. Contributions to Mineralogy and Petrology, 151, 539-557.

Acosta-Vigil, A., Cesare, B., London, D., Morgan, G. B., VI (2007). Microstructures and composition of melt inclusions in a crustal anatectic environment, represented by metapelitic enclaves within El Hoyazo dacites, SE Spain. Chemical Geology 235, 450-465.

Acosta-Vigil, A., Buick, I., Hermann, J., Cesare, B., Rubatto, D., London, D., Morgan, G. B.,VI (2010). Mechanisms of crustal anatexis: a geochemical study of partially melted metapelitic enclaves and host dacite, SE Spain. Journal of Petrology 51, 785-821.

Acosta-Vigil, A., Barich, A., Bartoli, O. et al. (2016). The composition of nanogranitoids in migmatites overlying the Ronda peridotites (Betic Cordillera, S Spain): the 
anatectic history of a polymetamorphic basement. Contributions to Mineralogy and Petrology, 171, 24. https://doi.org/10.1007/s00410-016-1230-3

Acosta-Vigil, A., London, D., Morgan, G. B., VI, Cesare, B., Buick, I., Hermann, J., Bartoli, O. (2017). Primary crustal melt compositions: Insights into the controls, mechanisms and timing of generation from kinetics experiments and melt inclusions. Lithos, 286-287, 454-479. doi:10.1016/j.lithos.2017.05.020

Alonso-Perez, R., Müntener, O., Ulmer, P. (2008). Igneous garnet and amphibole fractionation in the roots of island arcs: experimental constraints on andesitic liquids.

Contributions to Mineralogy and Petrology, 157, 541-558. 10.1007/s00410-008-0351-8.

604 Aubaud, C., Withers, A. C., Hirschmann, M. M., Guan, Y., Leshin, L. A., Mackwell, 605 S. J., Bell, D. R. (2007). Intercalibration of FTIR and SIMS for hydrogen measurements in 606 glasses and nominally anhydrous minerals. American Mineralogist, 92, 811-828.

Bartoli, O., Cesare, B., Poli, S., Acosta-Vigil, A., Esposito, R., Turina, A., Bodnar, R.J., Angel, R.J., Hunter, J. (2013a). Nanogranite inclusions in migmatitic garnet: behavior during pis- ton cylinder re-melting experiments. Geofluids 13, 405-420.

Bartoli, O., Cesare, B., Poli, S., Bodnar, R.J., Acosta-Vigil, A., Frezzotti, M.L., Meli, S. (2013b). Recovering the composition of melt and the fluid regime at the onset of crustal anatexis and S-type granite formation. Geology, 41, 115-118. CONTROLLARE 2013 abc 
Bartoli, O., Tajčmanová, L., Cesare, B., Acosta-Vigil, A., (2013c). Phase equilibria

constraints on melting of stromatic migmatites from Ronda (S. Spain): insights on the formation of peritectic garnet. Journal of Metamorphic Geology, 31, 775-789.

Bartoli, O., Acosta-Vigil, A., Ferrero, S., and Cesare, B. (2016). Granitoid magmas preserved as melt inclusions in high-grade metamorphic rock. American Mineralogist, 101, 1543-1559.

Bartoli, O., Cesare, B., Remusat, L., Acosta-Vigil, A., Poli, S. (2014). The $\mathrm{H}_{2} \mathrm{O}$

content of granite embryos. Earth and Planetary Science Letters, 395, 281-290.

doi:10.1016/j.epsl.2014.03.031

Bartoli, O. (2017). Phase equilibria modelling of residual migmatites and granulites: an valuation of the melt-reintegration approach. Journal of Metamorphic Geology, 35, 919942.
Behrens, H., Jantos, N. (2001) The effect of anhydrous composition on water solubility in granitic meltsAmerican Mineralogist, 86, 14-20.

Bomparola, R.M., Belousova, E., Ghezzo, C., Griffin, W.L., O'Reilly, Y.O. (2006).

Resetting of the U-Pb zircon system in Cambro-Ordovician intrusives of the Deep Freeze Range, northern Victoria Land, Antarctica. Journal of Petrology, 48, 327-364.

Borg, S. G., De Paolo, D. J., and Smith, B. M. (1990). Isotopic structure and tectonics of the central Transantarctic Mountains. Journal of Geophysical Research, 95, 6647-6667. 
Bradshaw, J. D., Laird, M.G. (1983). The pre-beacon geology of Northern Victoria

Land. In: Oliver, R.L., James, P.R., Jago, J.B. (Eds.), Antarctic Earth Science. Australian

Academy of Science, Canberra, pp. 98-101.

Brooker, R. A., Kohn, S. C., Holloway, J. R., McMillan, P. F., Carroll, M. R. (1999).

Solubility, speciation and dissolution mechanisms for $\mathrm{CO}_{2}$ in melts on the $\mathrm{NaAlO}_{2}-\mathrm{SiO}_{2}$ join.

Geochimica et Cosmochimica Acta, 63, 21, 3549-3565.

Bureau, H., Trocellier, P., Shaw, C., Khodja, H., Bolfan-Casanova, N., and

Demouchy, S., (2003). Determination of the concentration of water dissolved in glasses and minerals using nuclear microprobe. Nucl. Instrum. Methods Phys. Res., Sect. B 210, 449454.

Capponi, G., Crispini, L., Meccheri, M. (1999). Structural history and tectonic evolution of the boundary between the Wilson and Bowers Terranes, Lanterman Range, Northern Victoria Land, Antarctica. Tectonophysics, 312, 249-266. http://dx.doi.org/10. 1016/S0040-1951(99)00174-2.

Capponi G., Castorina F., Di Pisa A., Meccheri M., Petrini R., Villa, I. M., (2002). The meta-igneous rocks of the Barber Glacierarea (northern Victoria Land, Antarctica): a clue to theenigmatic Borchgrevink Orogeny? In: Gamble J., SkinnerD.N.B. 663 and Henrys S. (eds.), Antarctica at the close of amillennium. Royal Society of New 664 Zealand Bulletin, 35, 99-104. 
Carvalho, B. B., Bartoli, O., Ferri, F., Cesare, B., Ferrero, S., Remusat, L., Capizzi,

L.S., Poli, S. (2019). Anatexis and fluid regime of the deep continental crust: New clues from melt and fluid inclusions in metapelitic migmatites from ivrea zone (NW italy). Journal of Metamorphic Geology, 37, 951-975. doi:10.1111/jmg.12463

Cawood, P. (2005). Terra Australis Orogen: Rodinia breakup and development of the

Pacific and Iapetus margins of Gondwana during the Neoproterozoic and Paleozoic. EarthScience Reviews, 69, 249-279.

Cesare, B. (1999). Multi-stage pseudomorphic replacement of garnet during

polymetamorphism: 1. microstructures and their interpretation. Journal of Metamorphic

Geology, 17, 723-734. doi:10.1046/j.1525-1314.1999.00229.x

Cesare, B., Acosta-Vigil, A., Bartoli, O., Ferrero, S. (2015). What can we learn from melt inclusions in migmatites and granulites? Lithos, 239, 186-216.

Castelli, D., Oggiano, G., Talarico, F., Belluso, E., and Colombo, F. (2003). Mineral chemistry and petrology of the Wilson Terrane Metamorphics from Retreat Hills to Lady

Newnes Bay, northern Victoria Land, Antarctica. In: Ricci C.A. and Tessensohn F. (Eds.), Aspects of a suture zone, Marner Glacier area Antarctica. Geologisches Jahrbuch B, 85, 133172.

Coggon, R., Holland, T. J. B. (2002). Mixing properties of phengiticmicas and revised garnet-phengite thermobarometers. Journal of Metamorphic Geology, 20, 683-696. 
Connolly, J. A. D. (2009). The geodynamic equation of state: What and how.

Geochemistry, Geophysics, Geosystems, 10, Q10014.

Connolly, J. A. D., Cesare, B. (1993). C-O-H-S fluid composition and oxygen fugacity in graphitic metapelites. Journal of Metamorphic Geology, 11, 368-378.

Conrad, W. K., Nicholls, I. A., and Wall, V. J. (1988). Water-saturated and undersaturated melting of metaluminous and peraluminous crustal compositions at $10 \mathrm{~kb}$ :

Evidence for the origin of silicic magmas in the Taupo volcanic zone, New Zealand, and other occurrences. Journal of Petrology, 29, 765-803. doi:10.1093/petrology/29.4.765

Crispini, L., Di Vincenzo, G., Palmeri, R. (2007). Petrology and 40Ar-39Ar dating of shear zones in the Lanterman Range (northern Victoria Land, Antarctica): implications for the metamorphic and temporal evolution at terrane boundaries. Mineralogy and Petrology, 89, 217-249. http://dx.doi.org/10.1007/s00710-006-0164-2.

Di Vincenzo, G., Palmeri, R., Talarico, F., Andriessen, P. A. M., Ricci, C. A. (1997).

Petrology and geochronology of eclogites from the Lanterman Range. Antarctica. Journal of Petrology, 38, 1391-1417.

Di Vincenzo, G., Ghiribelli, B., Giorgetti, G., Palmeri, R. (2001). Evidence of a close

link between petrology and isotope records: constraints from SEM, EMP, TEM and in situ 40Ar-39Ar laser analyses on multiple generations of white micas (Lanterman Range, Antarctica). Earth and Planetary Science Letters, 192, 389-405. 
Di Vincenzo, G., Grande, A., Rossetti, F. (2014). Paleozoic siliciclastic rocks from

northern Victoria Land (Antarctica): provenance, timing of deformation and implications for the Antarctica/Australia connection. Geological Society of America Bulletin 126, 1416-1438.

Di Vincenzo, G., Horton F., Palmeri, R. (2016). Protracted ( 30 Ma) eclogite-facies metamorphism in northern Victoria Land (Antarctica): Implications for the geodynamics of the Ross/Delamerian Orogen. Gondwana Research, 40, 91-106.

Federico, L., Capponi, G., Crispini, L. (2006). The Ross orogeny of the transantarctic mountains: a northern Victoria Land perspective. International Journal of Earth Sciences (Geol Rundsch) 95, 759. https://doi.org/10.1007/s00531-005-0063-5.

Federico, L., Crispini, L., Capponi, G. (2010). Fault-slip analysis and transpressional tectonics: a study of Paleozoic structures in northern Victoria Land, Antarctica. Journal of Structural Geology, 32, 667-684.

Ferrero, S., Bartoli, O., Cesare, B., Salvioli, Mariani, E., Acosta-Vigil, A., Cavallo, A., Groppo, C., Battiston, S. (2012). Microstructures of melt inclusions in anatectic metasedimentary rocks. Journal of Metamorphic Geology, 30, 303-322.

Ferrero, S., Wunder, B., Walczak, K., O’Brien, P. J., Ziemann, M. A. (2015).

Preserved near ultrahigh-pressure melt from continental crust subducted to mantle depths.

Geology, 43, 447-450 doi:10.1130/ G36534.1. 
Ferrero, S., Godard, G., Palmeri, R., Wunder, B., and Cesare B. (2018). Partial

melting of ultramafic granulites from Dronning Maud Land, Antarctica: Constraints from

melt inclusions and thermodynamic modelling. American Mineralogist, 103, 610-622

https://doi.org/10.2138/am-2018-6214.

Frost, B.R., Barnes, C.G., Collins, W.J., Arculus, R.J., Ellis, D.J., and Frost, C.D. (2001). A geochemical classification for granitic rocks. Journal of Petrology, 42, 2033-2048.

Ghezzo, C., Baldelli, C., Biagini, R., Carmignani, L., Di Vincenzo, G., Gosso, G., Lelli, A., Lombardo, B., Montrasio, A., Pertusati, P. C., Salvini, F. (1989). Granitoids from the David Glacier \pm Aviator Glacier segment of the Transantarctic Mountains (Victoria Land Antarctica). In: Ricci CA (ed.) Proceedings of the Meeting: Geosciences in Victoria Land, Antarctica, Siena, September 2-3 1987. Mem Soc Geol Ital: 143-159.

Ghiribelli, B. (2000). Evoluzione tettonica e metamorfica del margine attivo del

Gondwana: Lanterman e Salamander Ranges (Antartide) Unpublished Ph.D. Thesis Siena University, p. 127 pp.

Ghiribelli, B., Frezzotti, M.L., Palmeri, R. (2002). Coesite in eclogites of the Lanterman Range (Antarctica): evidence from textural and raman spectroscopy studies.

European Journal of Mineralogy, 14, 355-360. 
Godard, G., and Palmeri, R. (2013). High-pressure metamorphism in Antarctica from the Proterozoic to the Cenozoic: A review and geodynamic implications. Gondwana Research, 23, 844-864, http://dx.doi.org/10.1016/j.gr.2012.07.012

Grant, J. A. (2009). Thermocalc and experimental modelling of melting of pelite, morton pass, Wyoming. Journal of Metamorphic Geology, 27, 571-578. doi:10.1111/j.15251314.2009.00846.x

Grew, E.S., Kleinschmidt, G., Schubert, W. (1984). Contrasting metamorphic belts in north Victoria Land, Antarctica. Geologisches Jahrbuch B60, 253-263.

Hiroi, Y., Hokada, T., Kato, M., et al. (2019). Felsite-nanogranite inclusions and three Al2SiO5 polymorphs in the same garnet in ultrahigh-temperature granulites from Rundvågshetta, Lützow-Holm Complex, East Antarctica. Journal of Mineralogical and Petrological Sciences, 114, 60-78, doi 10.2465/jmps.181118.

Holland, T. J. B., and Powell, R. (1998). An internally consistent ther- modynamic 
Holland, T. J. B., Powell, R. (2003). Activity-composition relations for phases in

petrological calculations: An asymmetric multicom- ponent formulation. Contributions to Mineralogy and Petrology, 145, 492-501.

Holness, M. B., Cesare, B., Sawyer, E.W. (2011). Melted rocks under the microscope: microstructures and their interpretation. Elements, 7, 247-252.

Holtz, F., Johannes, W., Tamic, N., Behrens, H. (2001). Maximum and minimum water contents of granitic melts generated in the crust: A reevaluation and implications. Lithos, 56, 1-14.

Holtz, F., Johannes, W. (1991). Genesis of peraluminous granites I. experimental investigation of melt compositions at 3 and $5 \mathrm{~kb}$ and various $\mathrm{H}_{2} \mathrm{O}$ activities. Journal of Petrology, 32, 935-958. doi:10.1093/petrology/32.5.935

Holtz, F., Johannes, W. (1992). Peraluminous granites: The effect of alumina on melt composition and coexisting minerals. Transactions of the Royal Society of Edinburgh: Earth Sciences, 83, 409-416. doi:10.1017/S0263593300008075

Huang, W. L., Wyllie, P. J. (1975). Melting reactions in the system $\mathrm{NaA}_{1} \mathrm{Si}_{3} \mathrm{O}_{8^{-}}$ $\mathrm{KA}_{1} \mathrm{Si}_{3} \mathrm{O}_{8}-\mathrm{SiO}_{2}$ to 35 kilobars, dry and with excess water. Journal of Geology, 83, 737-748.

Kleinschmidt, G., Tessensohn, F. (1987). Early Paleozoic westward directed 812 subduction at the Pacific continental margin of Antarctica, sixth Gondwana symposium. 813 American Geophysical Union, Geophysical Monograph 40, 89-105. 
Luth, W.C., Jahns, R.H., Tuttle, O.F. (1964) The granite system at pressure of 4 to 10

kilobars. Journal of Geophysical Research, 69, 759-773.

Morgan VI, G.B., London, D. (2005). The effect of current density on the electron microprobe analysis of alkali aluminosilicate glasses. American Mineralalogist, 90, 11311138.

Newton, R. C., Charlu, T. V., Kleppa, O. J. (1980). Thermochem- istry of high structural state plagioclases. Geochimica et Cosmochimica Acta, 44, 933-941.

Palmeri, R., Talarico, F., Meccheri, M., Oggiano, G., Pertusati, P.C., Rastelli, N., Ricci, C.A. (1991). Progressive deformation and low pressure/high temperature metamorphism in the Deep Freeze Range, Wilson Terrane, northern Victoria Land, Antarctica. Memorie della Società Geologica Italiana, 46, 179-195.

Palmeri, R., Pertusati, P.C., Ricci, C.A., Talarico, F. (1994). Late Proterozoic(?)-early

Paleozoic of the active pacific margin of Gondwana: evidence from the southern Wilson terrane (northern Victoria Land, Antarctica). Terra Antartica, 1, 5-9.

Palmeri, R. (1997). P-T paths and migmatite formation: An example from Deep

Freeze Range, northern Victoria Land, Antarctica. Lithos, 42, 47-66.

Palmeri, R., Ghiribelli, B., Talarico, F., Ricci, C.A. (2003). Ultra-high-pressure 838 metamorphism in felsic rocks: the garnet-phengite gneisses and quartzites from the 
Lanterman Range. Antarctica: European Journal of Mineralogy, 15, 513-525.

http://dx.doi.org/ 10.1127/0935-1221/2003/0015-0513.

Palmeri, R., Ghiribelli, B., Ranalli, G., Talarico, F., Ricci, C.A. (2007). Ultrahigh-

pressure meta- morphism and exhumation of garnet-bearing ultramafic rocks from the

Lanterman Range (northern Victoria Land, Antarctica). Journal of Metamorphic Geology, 25, 225-243. http://dx.doi.org/10.1111/j.1525-1314.2006.00686.x.

Palmeri, R., Frezzotti, M.L., Godard, G., Davies, J. (2009). Pressure-induced incipient amorphization of $\alpha$-quartz and transition to coesite in an eclogite from Antarctica: a first record and some consequences. Journal of Metamorphic Geology, 27, 685-705.

Palmeri, R., Talarico, F.M., Ricci, C.A. (2011). Ultrahigh-pressure metamorphism at the Lanterman Range (northern Victoria Land, Antarctica). Geological Journal, 46, 126-136.

Patiño Douce, A.E., Beard, J.S. (1996). Effects of $\mathrm{P}, \mathrm{f}(\mathrm{O} 2)$ and $\mathrm{Mg} / \mathrm{Fe}$ ratio on dehydration-melting of model metagraywackes. Journal of Petrology, 37, 999-1024.

Redler, C., Johnson, T. E., White, R. W., and Kunz, B. E. (2012). Phase equilibrium constraints on a deep crustal metamorphic field gradient: Metapelitic rocks from the Ivrea Zone (NW Italy). Journal of Metamorphic Geology, 30, 235-254, https://doi.org/10. $\underline{1111 / j .1525-1314.2011 .00965 . x}$ 
Eclogite at the Antarctic palaeo-Pacific active margin of Gondwana (Lanterman Range,

northern Victoria Land, Antarctica). Antarctic Science, 8, 277-280.

Ricci, C.A., Talarico, F., and Palmeri, R. (1997). Tectonothermal evolution of the Antarctic paleo-pacific active margin of Gondwana: a northern Victoria Land perspective. In:

Ricci, C.A. (Ed.), The Antarctic Region: Geological Evolution and Processes. Terra Antartica Publications, Siena, 213-218.

Ricci, C.A., and Tessensohn, F. (2003). The Lanterman-Mariner suture: Antarctic evidence for active margin tectonics in Paleozoic Gondwana. Geologisches Jahrbuch B85, $303-332$.

Rocchi, S., Di Vincenzo, G., Ghezzo, C. (2004). The Terra Nova Intrusive Complex (Victoria Land, Antarctica), with 1:50000 geopetrographic map. Terra Antartica Reports 10, 51.

Roedder, E. (1984). Fluid inclusions. Mineralogical Society of America, Reviews in Mineralogy, 12, 644 pp.

Stump, E. (1995). The Ross Orogen of the transantarctic mountains. Cambridge University Press, Cambridge. 284 pp.

Tacchetto, T., Bartoli, O., Cesare, B., Berkesi, M., Aradi, L. E., Dumond, G., Szabó, C. (2019). Multiphase inclusions in peritectic garnet from granulites of the Athabasca 
8

granulite terrane (Canada): Evidence of carbon recycling during Neoarchean crustal melting.

Chemical Geology, 508, 197-209, https://doi.org/10.1016/j.chemgeo.2018.05.043.

Tajčmanová, L., Connolly, J. A. D., Cesare, B. (2009). A thermodynamic model for titanium and ferric iron solution in biotite. Journal of Metamorphic Geology, 27, 153-165.

Talarico, F., Borsi, L., Lombardo, B. (1995). Relict granulites in the Ross Orogen of northern Victoria Land (Antarctica), II. Geochemistry and palaeo-tectonic implications.

Precambrian Research, 75, 157-174. http://dx.doi.org/10.1016/0301-9268(95)80004-2.

Talarico, F., Ghiribelli, B., Smith, S.C., Palmeri, R., Ricci, C.A. (1998). The northern Victoria Land segment of the Antarctic paleo-Pacific margin of eastern Gondwana: new constraints from the Lanterman and Mountaineer Ranges. Terra Antartica, 5, 245-252.

Talarico, F., Palmeri, R., and Ricci, C.A. (2004). Regional metamorphism and P-T evolution of the Ross orogen in northern Victoria Land (Antarctica): A review. Periodico Mineralogia, 73, 185-196.

Tamic, N., Behrens, H., Holtz, F. (2001). The solubility of $\mathrm{H}_{2} \mathrm{O}$ and $\mathrm{CO}_{2}$ in rhyolitic melts in equilibrium with a mixed $\mathrm{CO}_{2}-\mathrm{H}_{2} \mathrm{O}$ fluid phase. Chemical Geology, 174, 333-347.

Thomen, A., Robert, F., Remusat, L. (2014). Determination of the nitrogen abundance 909 in organic materials by NanoSIMS quantitative imaging. J. Anal. At. Spectrom. 29, 512-519. 
Thompson, J. B., Hovis, G. L. (1979). Entropy of mixing in sanidine. American

6

Mineralogist, 64, 57-65.

Wallace, P. J., Kamenetsky, V. S., and Cervantes, P. (2015). Melt inclusion $\mathrm{CO}_{2}$

contents, pressures of olivine crystallization, and the problem of shrinkage bubbles. American

Mineralogist, 100, 787-794, 003-004X/15/0004-87\$05.00/DOI:http://dx.doi.org/10.2138/am2015-5029

Wang, X., Chou, I. M., Hu, W., Burruss, R. C., Sun, Q., Song, Y. (2011). Raman

spectroscopic measurements of $\mathrm{CO}_{2}$ density: Experimental calibration with high-pressure optical cell

(HPOC) and fused silica capillary capsule (FSCC) with application to fluid inclusion observations.

Geochimica et Cosmochimica Acta, 75, 4080-4093.

Weinberg, R. F., Hasalová, P. (2015). Water-fluxed melting of the continental crust: A review. Lithos, 212, 158-188.

White, R. W., Powell, R., Holland, T. J. B. (2007). Progress relating to calculation of partial melting equilibria for metapelites. Journal of Metamorphic Geology, 25, 511-527.

White, R. W., Stevens, G., Johnson, T. E. (2011) Is the crucible reproducible?

Reconciling melting experiments with thermodynamic calculations. Elements, 7, 241246.

Wilke, S., Holtz, F., Neave, D. A., Almeev, R. (2017). The Effect of Anorthite

Content and Water on Quartz-Feldspar Cotectic Compositions in the Rhyolitic System and 
936 Implications for Geobarometry. Journal of Petrology, 2017, Vol. 58, No. 4, 789-818 doi:

\subsection{3/petrology/egx034}

\section{FIGURE CAPTIONS}

Figure 1 - Location of the Ross orogenic belt in the Transantarctic Mountains

(modified from Godard and Palmeri, 2013). A) Location map; B) geological sketch map of

Northern Victoria Land (RBT, Robertson Bay Terrane; BT, Bowers Terrane; WT, Wilson

Terrane; LR, Lanterman Range; SR, Salamander Range; MR, Mountaineer Range); C)

geological map of the Lanterman Range (after Ghiribelli, 2000) and location of the sampling area.

Figure 2 - Microphotographs of sample GO5 under optical microscope, plane polarized light (PPL). (A) Typical microstructure with muscovite and biotite growing along the main foliation, abundant plagioclase and quartz, garnet of ca. $400 \mu \mathrm{m}$. Cluster of inclusions (FI and PI) (B) along the rims of a large crystal of garnet, or (C) in the core of a tiny crystal of garnet partly replaced by down-grade biotite.

Figure 3 -Representative Raman spectra of phases and volatile species in: A) fluid inclusion; B) shrinkage bubble in remelted glass; C) remelted glass.

Figure 4 - Microstructures of MI under scanning electron microscope (BSE images) after remelting experiments in piston cylinder apparatus at increasing temperature: $740^{\circ} \mathrm{C}$ partially homogenized MI with glass (yellow arrows), quartz, biotite, muscovite, albite and ilmenite; $760^{\circ} \mathrm{C}$ - glassy $\mathrm{MI}$ with rounded quartz (= partial resorption); $780^{\circ} \mathrm{C}$ - glassy $\mathrm{MI}$ 960 with regular walls, negative crystal shape and crystals of $\mathrm{Ilm} ; 810^{\circ} \mathrm{C}$ - homogenized MI with 
961 local offshots (white arrows) and secondary acicular Bt; $850^{\circ} \mathrm{C}$ - homogenized MI with

lobate-cuspate walls, offshots (white arrows), and secondary Grt suggesting overheating and host interaction; $900^{\circ} \mathrm{C}$ - glassy MI with segmented straight walls after assimilation of host Grt (inset).

Figure 5 - Harker diagrams showing the major element concentrations (wt\%) of melt inclusions in crustal enclaves after remelting experiments at $740^{\circ} \mathrm{C}$ to $900^{\circ} \mathrm{C}$ (data in Table 3). (A) $\mathrm{MnO}$ vs. FeOtot. (B) $\mathrm{FeOt}+\mathrm{MgO}+\mathrm{TiO}_{2}$ vs. $\mathrm{SiO}_{2}$ with mixing vectors between the mineral pairs Grt-Qz and Feld-Qz (see text for details). (C) $\mathrm{CaO}$ vs. $\mathrm{SiO}_{2}$. (D) $\mathrm{Na}_{2} \mathrm{O}$ vs. $\mathrm{SiO}_{2}$. (E) $\mathrm{Al}_{2} \mathrm{O}_{3}$ vs. $\mathrm{SiO}_{2}$ with mixing vectors between the mineral pairs Grt-Qz and Feld-Qz. (F) ASI vs. $\mathrm{SiO}_{2}$.

Figure 6 - CIPW Qz-Ab-Or and An-Ab.Or diagrams showing the normative compositions of all analyzed melt inclusions. Blue and green circles are for glassy inclusions remelted at $760^{\circ} \mathrm{C}$ and $780^{\circ} \mathrm{C}$ respectively. Grey dotted lines show the eutectic points and cotectic lines for the subaluminous haplogranite system at $a \mathrm{H}_{2} \mathrm{O}=1$ and different pressures (Holtz and Johannes 1992; Luth et al. 1964; Huang and Wyllie 1975). Grey circles and lines represent the effect of different amounts of normative melt An at constant $100 \mathrm{MPa}$ pressure (data from James and Hamilton, 1969). References to experimental glasses from Ojén (Bartoli et al., 2013c) and El Hoyazo (Acosta-Vigil et al., 2007) where "met." refers to metatexites, and "diat." to diatexite.

Figure 7 - Composition of analyzed melt inclusions in (A) modified alkali-lime index $984\left(\mathrm{MALI}=\mathrm{Na}_{2} \mathrm{O}+\mathrm{K}_{2} \mathrm{O}-\mathrm{CaO}\right)$ vs. $\mathrm{SiO}_{2}(\mathrm{wt} \%)$ after Frost et al. (2001); (B) total alkali vs. $985 \mathrm{SiO}_{2}$ diagram. Symbols as in Fig. 6. 
Figure $8-\mathrm{H}_{2} \mathrm{O}$ and $\mathrm{CO}_{2}$ concentration of re-homogenized melt inclusions in experiments performed at $760^{\circ} \mathrm{C}$ (blu circles) and $780^{\circ} \mathrm{C}$ (green circles) at $0.8-1.0 \mathrm{GPa}$ measured by NanoSIMS. White circles in (B) and (C) are averages of analyses at $760^{\circ} \mathrm{C}$ and $780^{\circ} \mathrm{C}$. Horizontal bars are one standard deviation on average values. (D) Comparison of $\mathrm{H}_{2} \mathrm{O}$ with expected values from Holtz et al. (2001), cross symbols are averages at $760^{\circ} \mathrm{C}$ (green) and $780^{\circ} \mathrm{C}$ (blue).

Figure 9 - (A) P-T section for GO5 calculated in MnNCaKFMASHT system (bulk composition from XRF analysis). (B) Isomodes of biotite, garnet and melt. The green shaded area in B defines the calculated modal composition consistent with mass balance calculations.

Fig. 10 (Supplementary Material) - Compositional isopleths for $\mathrm{X}_{\mathrm{Pyr}}, \mathrm{X}_{\mathrm{Alm}}$ and $\mathrm{X}_{\mathrm{Spn}}$ in garnet, $X_{\mathrm{An}}$ in plagioclase, $\mathrm{X}_{\mathrm{Mg}}$ and Ti (a.p.f.u.) in biotite calculated in MnNCaKFMASHT system (bulk composition of GO5 from XRF analysis).

Fig. 11. P-T trajectory path for prograde to retrograde path of eclogite and felsic rocks from Lanterman Range (modified from Di Vincenzo et al., 2016). Blue box represents the estimated P-T conditions for partial melting in the Edixon Complex.

\section{TABLE CAPTIONS}

Table 1 (Supplementary Material) - Mean compositions (wt\%) of minerals from GO5

(standard deviations within brackets).

Table 2 - Experimental conditions of piston-cylinder remelting experiments. 
Table 3 - Major element composition (wt $\%$ ) of glasses in remelted inclusions on

${ }_{5}^{4} 1013$ anhydrous basis. Numbers in parentheses refer to $1 \sigma$ standard deviation.

6

71014

8

${ }_{10}^{9} 1015$

11

121016 inclusions by NanoSIMS.

13

14

15

16

17

18

19

20

21

22

23

24

25

26

27

28

29

30

31

32

33

34

35

36

37

38

39

40

41

42

43

44

45

46

47

48

49

50

51

52

53

54

55

56

57

58

59

60

61

62

63

64

65 


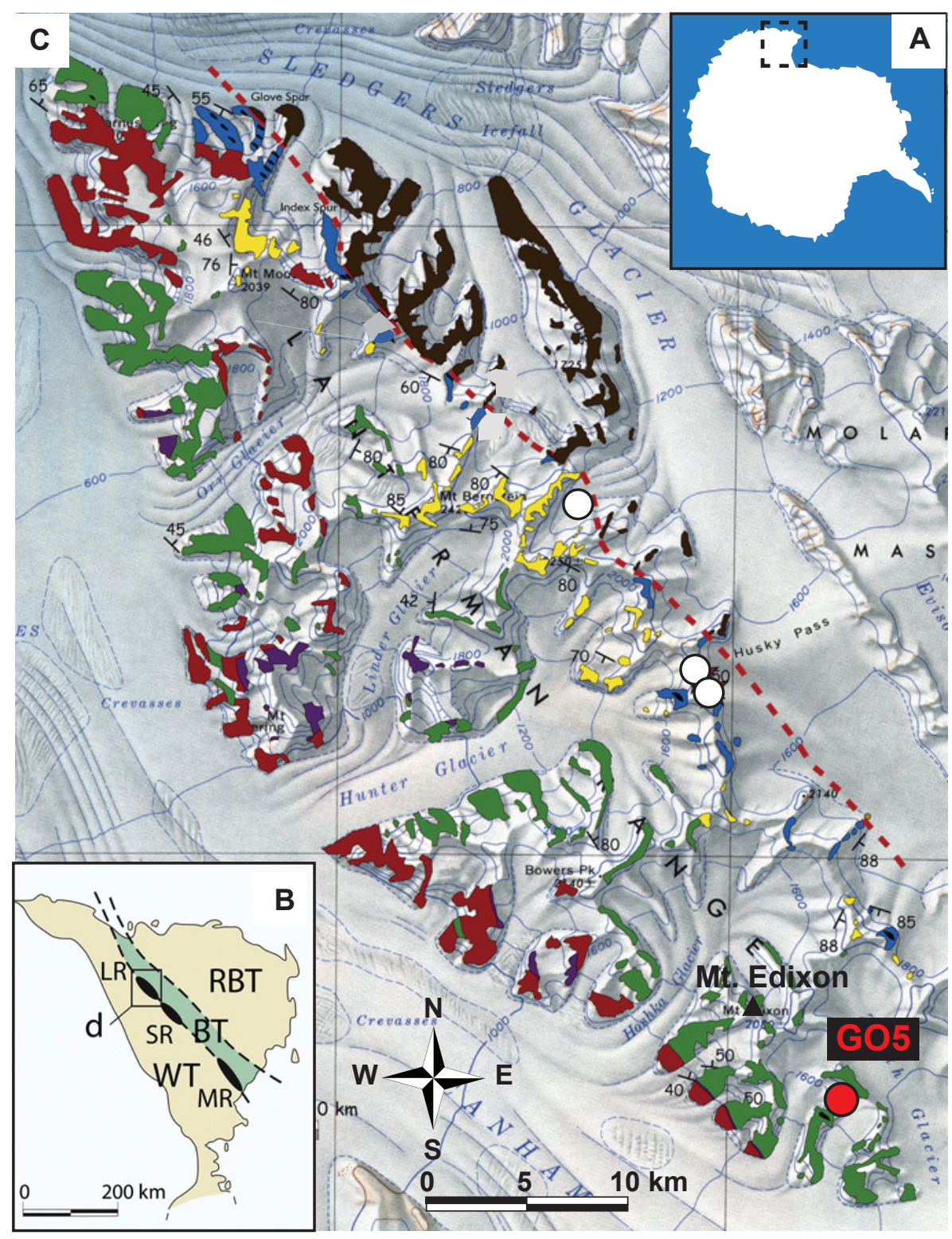

BOWERS TERRANE (BT)

sampling area

- - - - Lanterman Fault

\section{WILSON TERRANE (WT)}

Gateway Hills Metamorphic Complex (GHMC)

- eclogite facies rocks

Bernstein Metamorphic Complex (BMC)

Edixon Metamorphic Complex (EMC)

Granite Harbour Intrusives (GHI) 

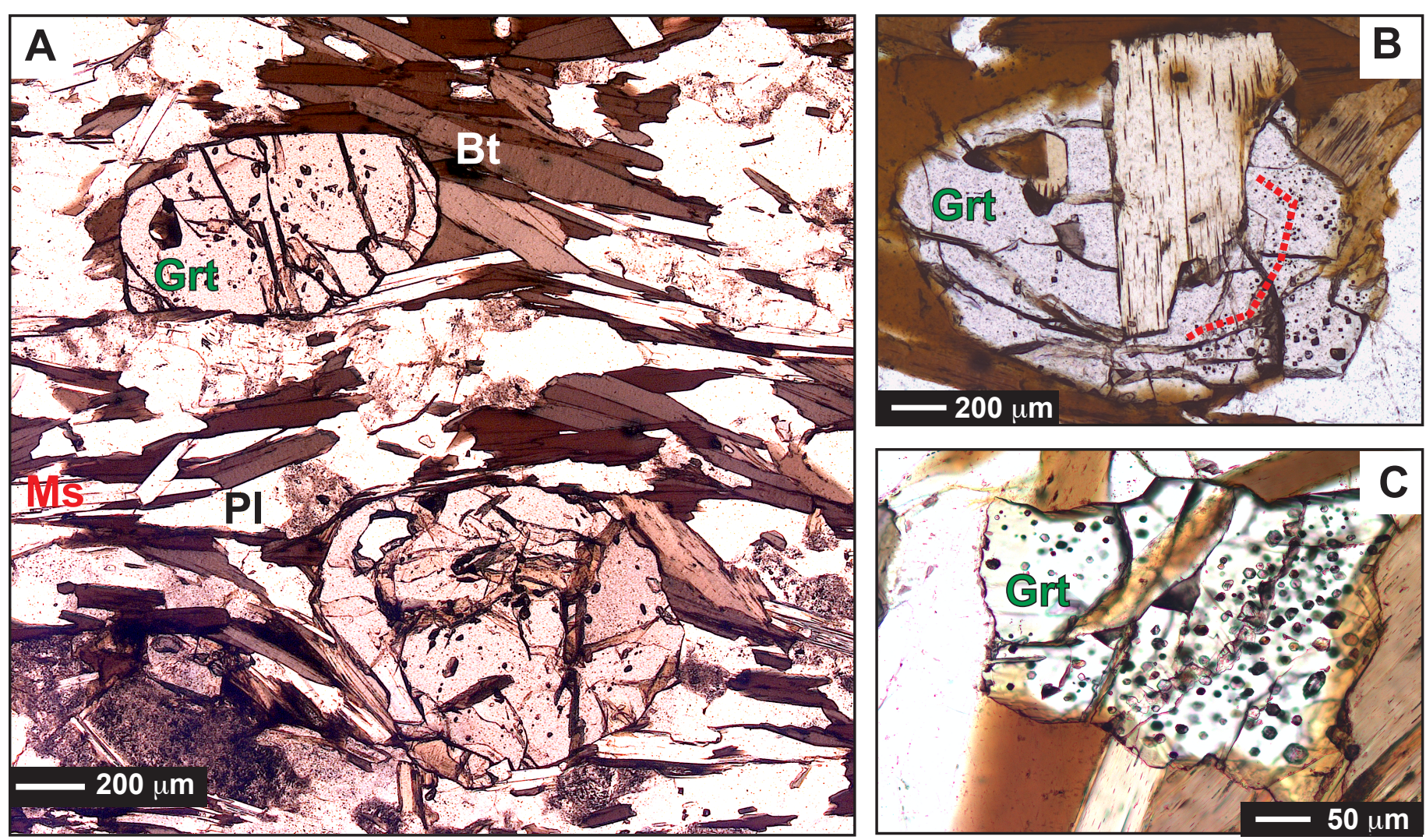

Figure 2 


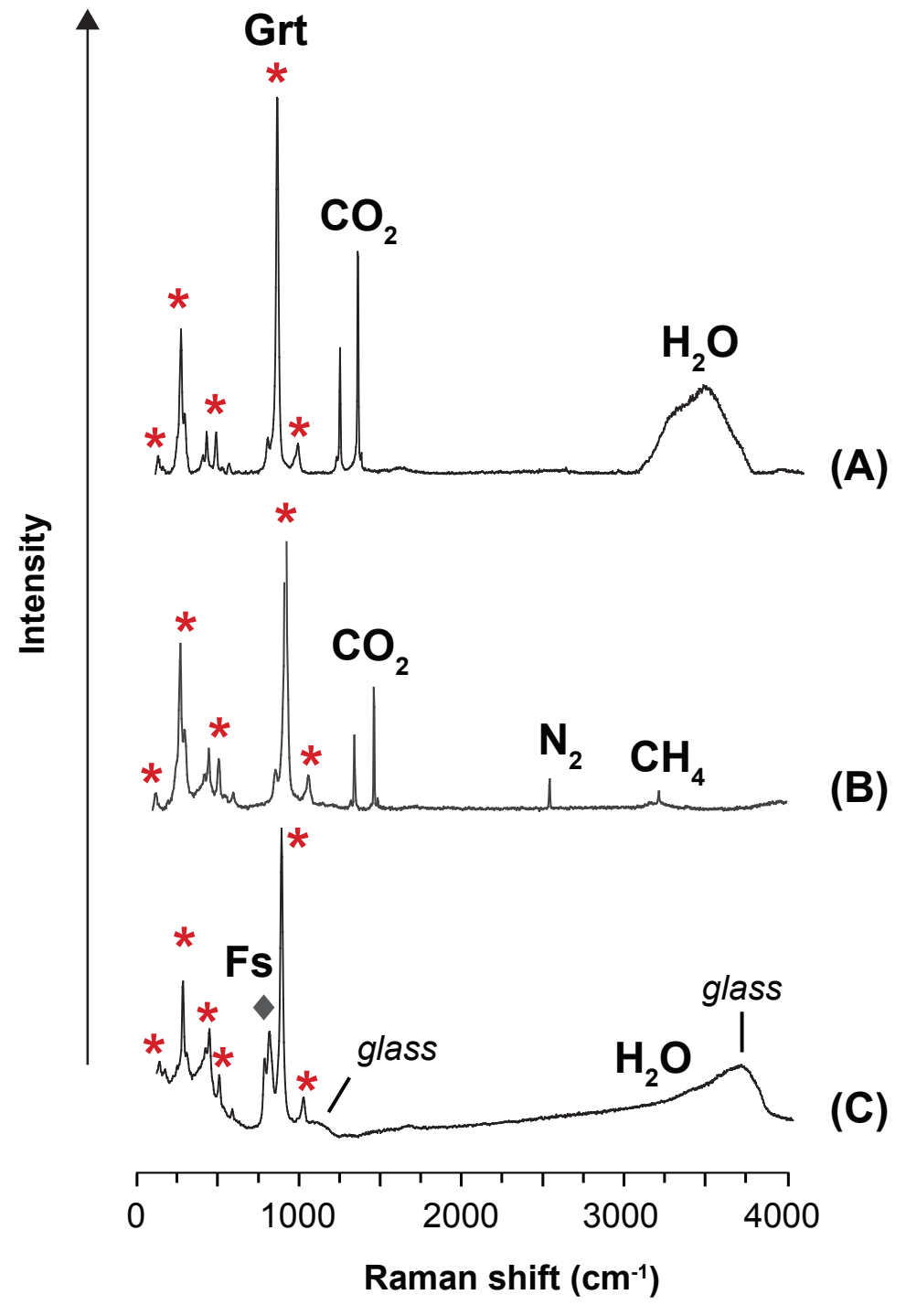

Figure 3 

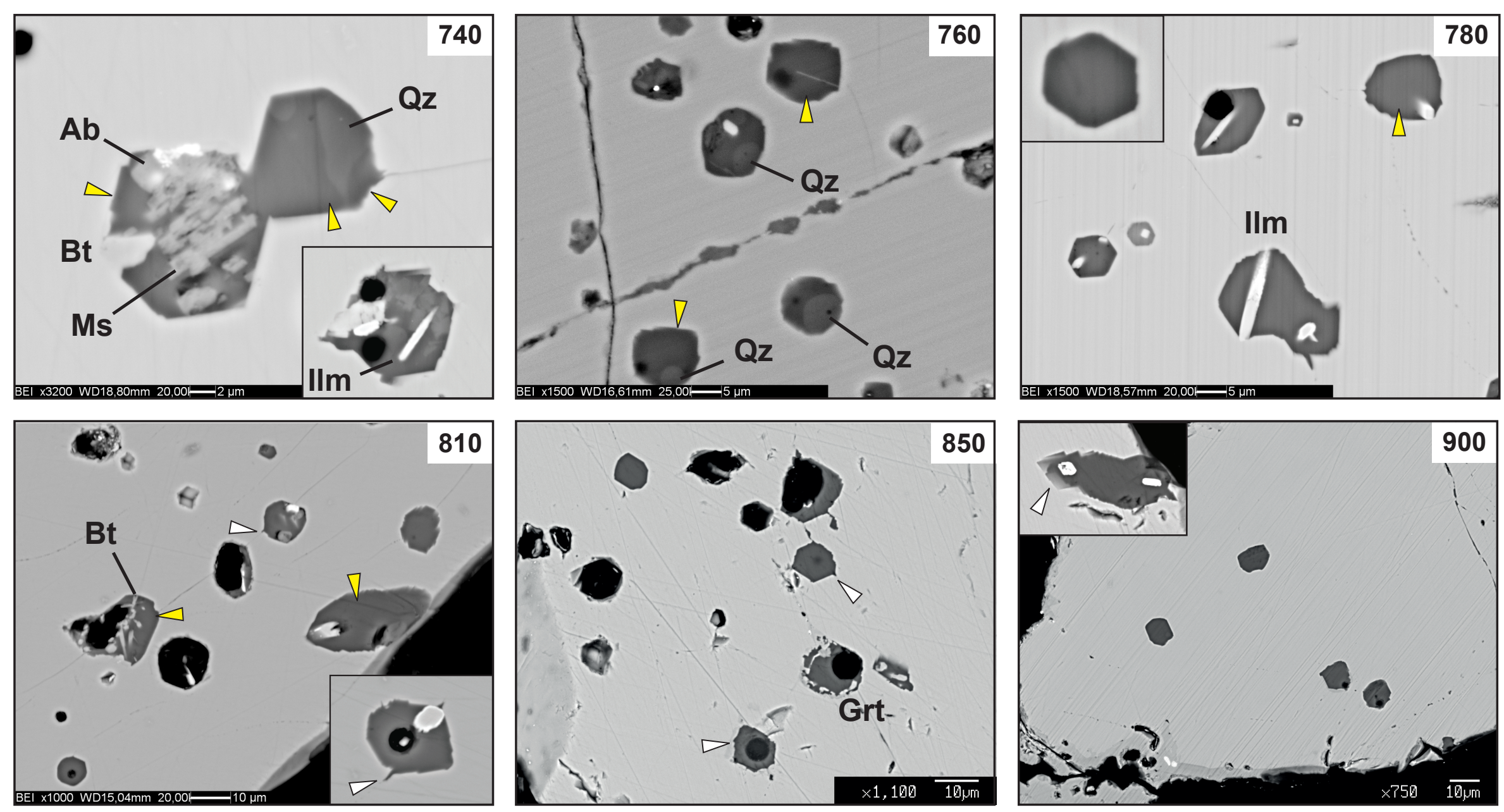

Figure 4 

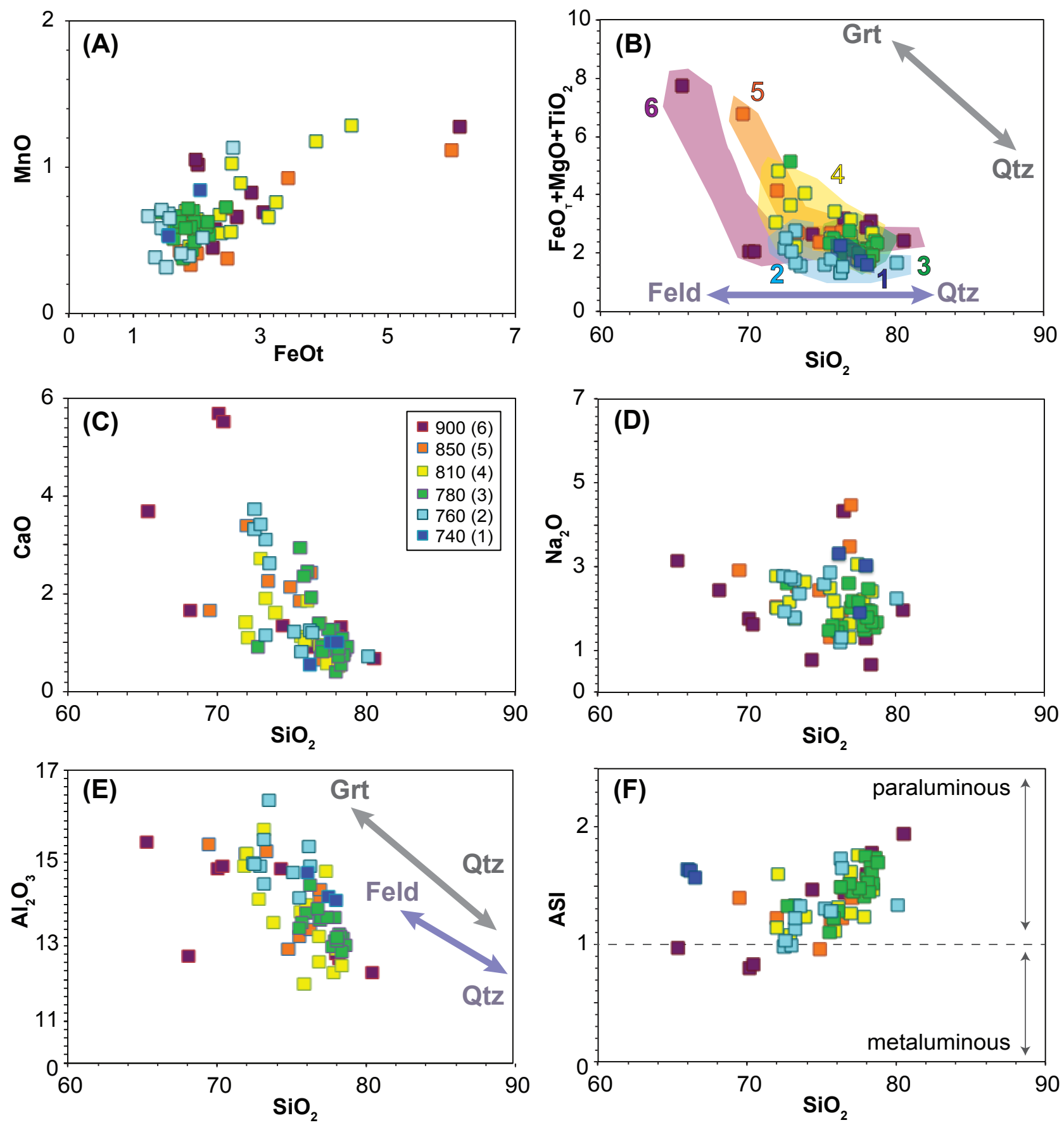

Figure 5 

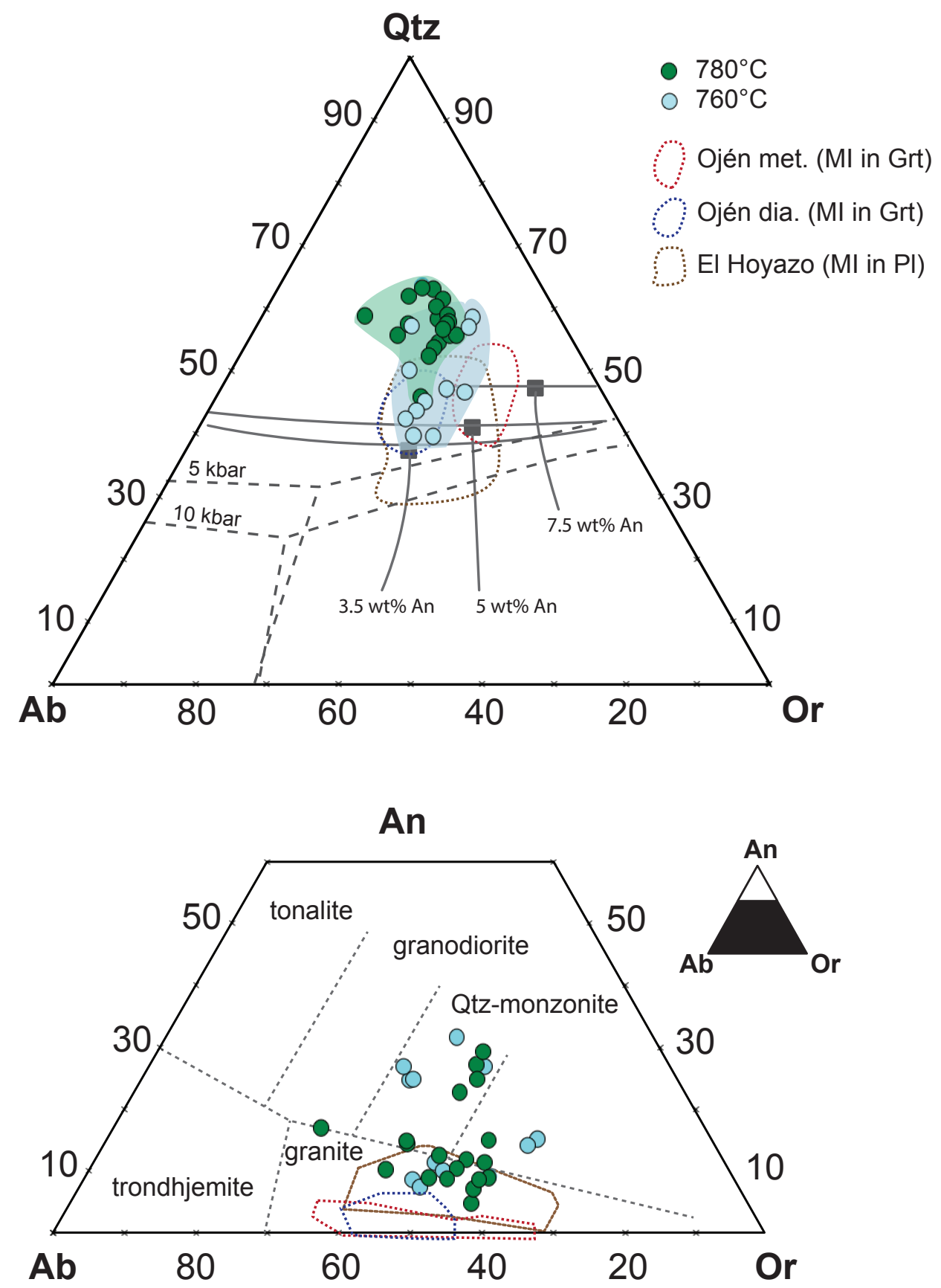

Figure 6 

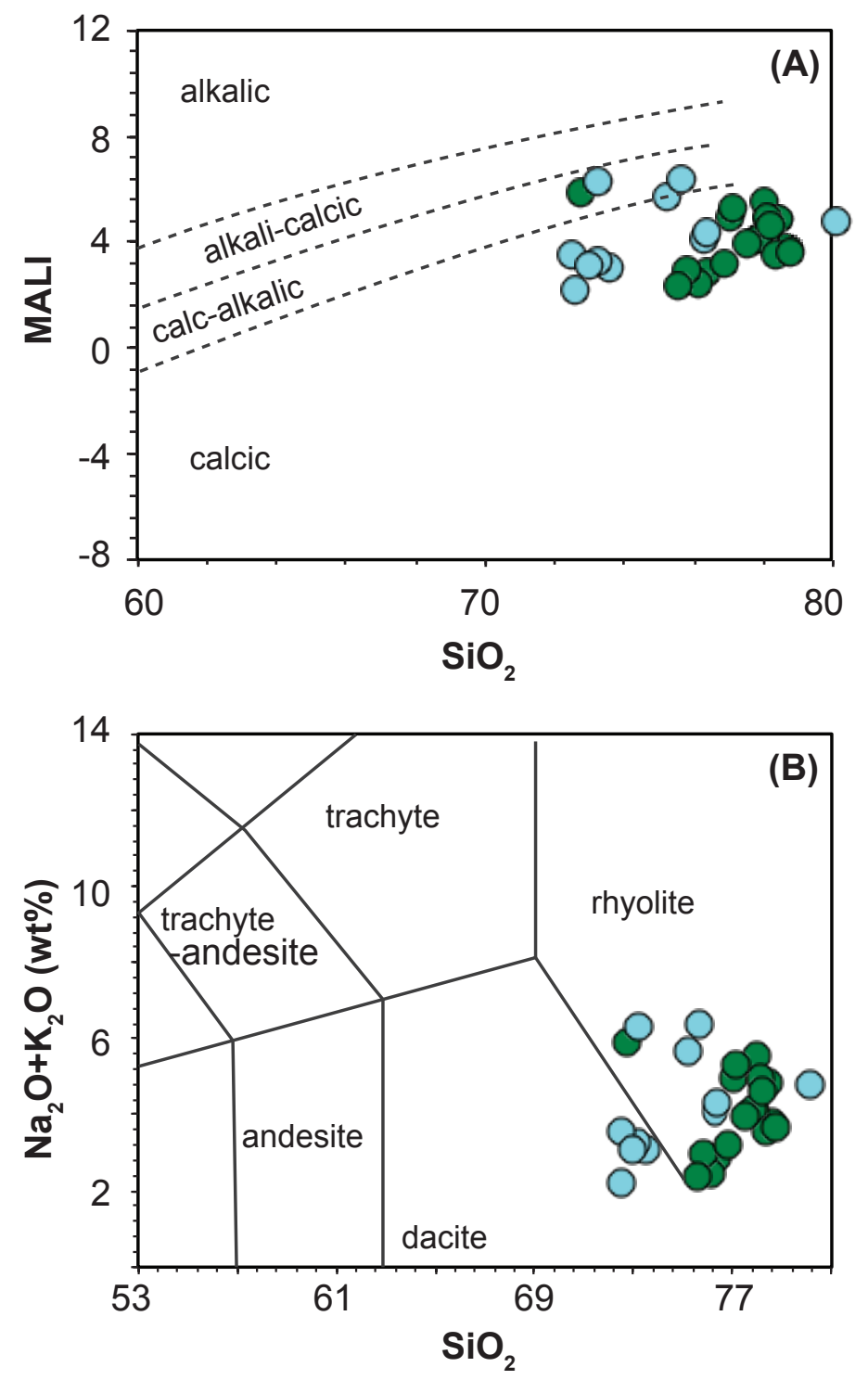

Figure 7 

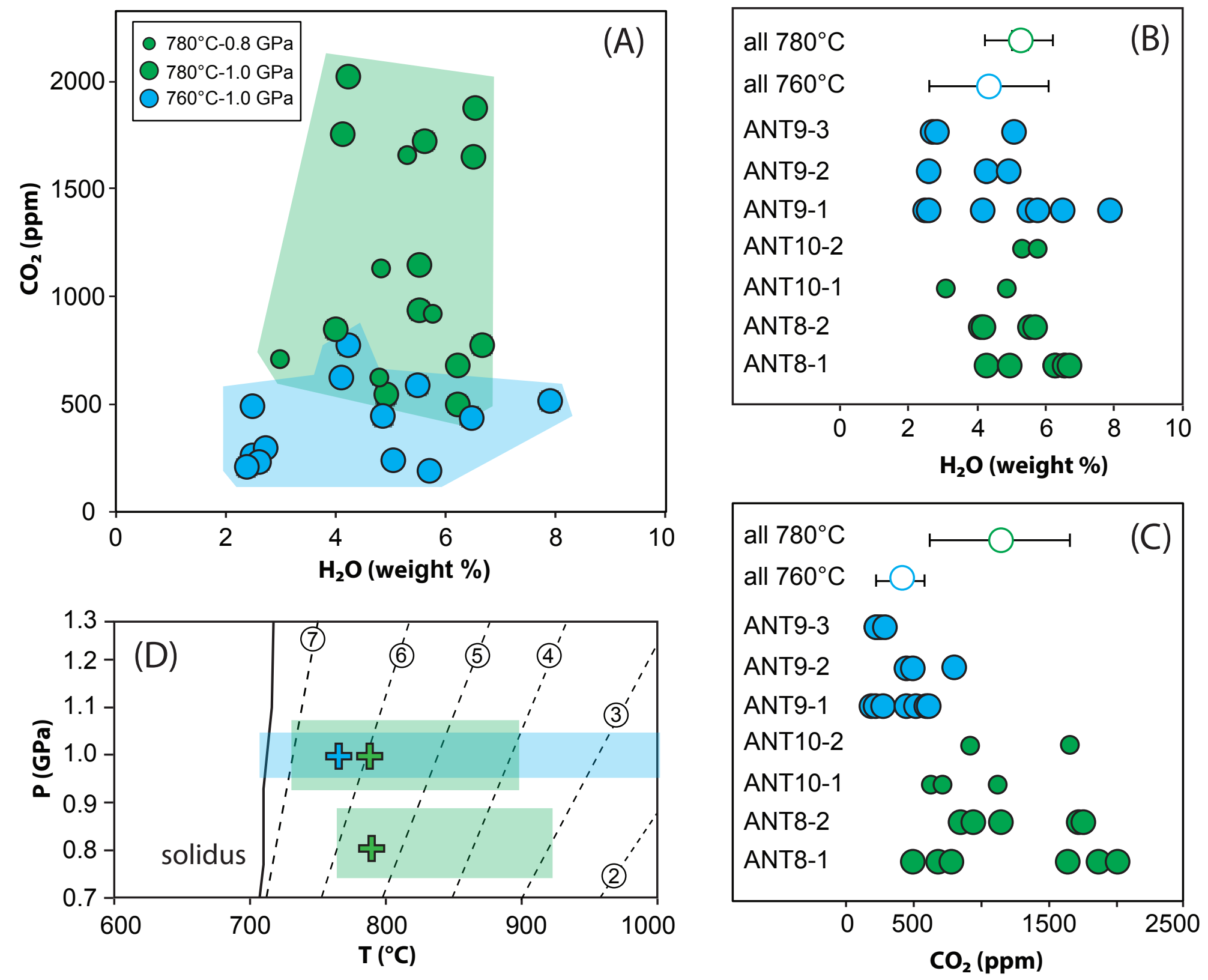

Figure 8 
(A)

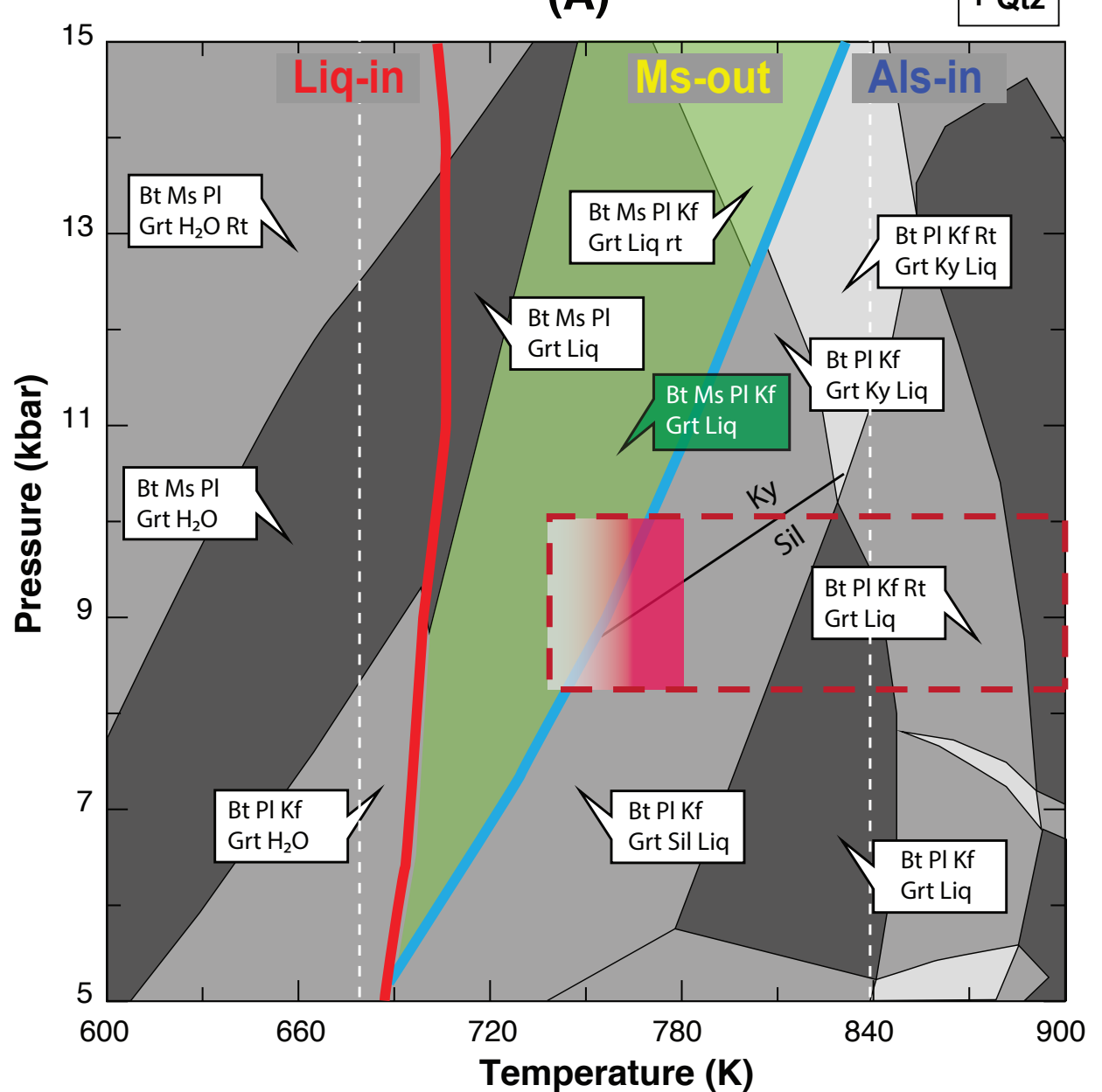

(B)

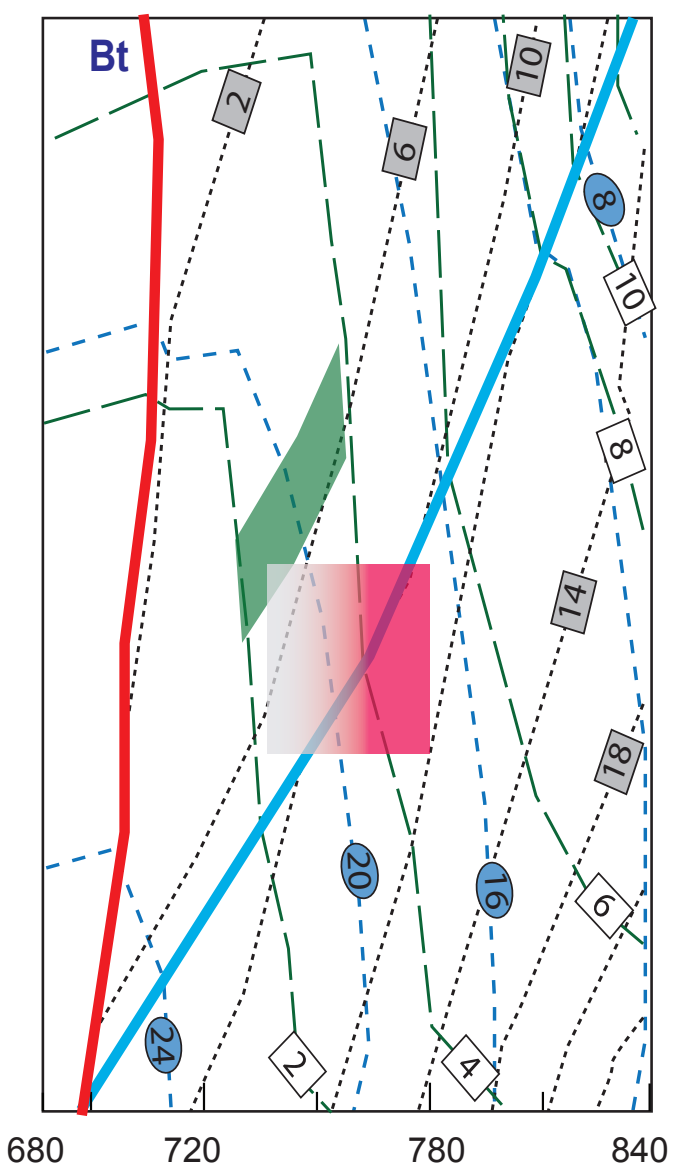

\section{MNCaKFMASHT}

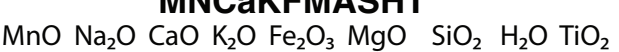
$\begin{array}{lllllllllll}\text { wt\% } & 0.26 & 1.60 & 0.98 & 3.68 & 6.51 & 2.53 & 69.99 & 1.51 & 0.67\end{array}$

$-1-$ Grt $\quad \cdots 2-$ melt - 3 - Bt

\section{Figure 9}



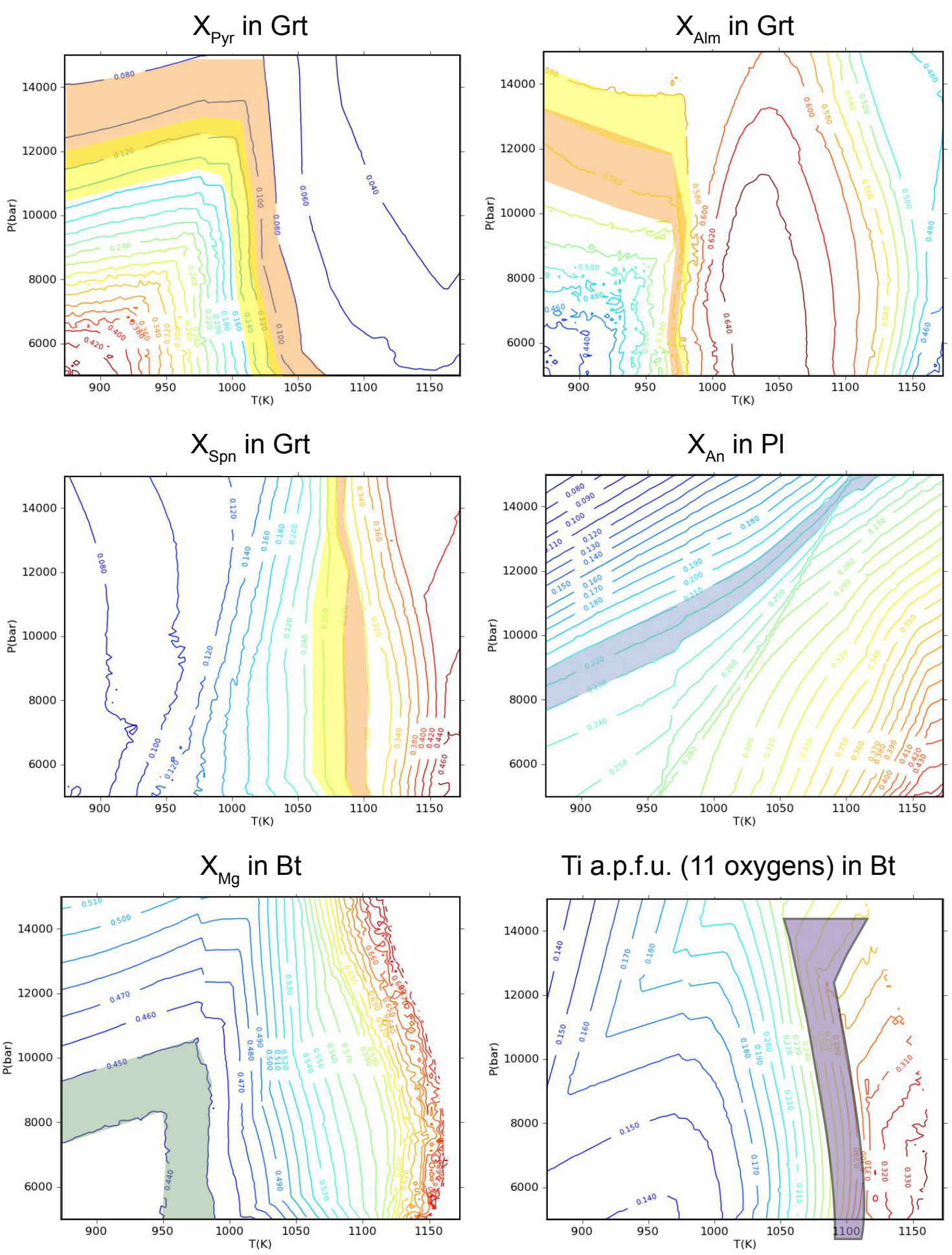

Ti a.p.f.u. (11 oxygens) in Bt
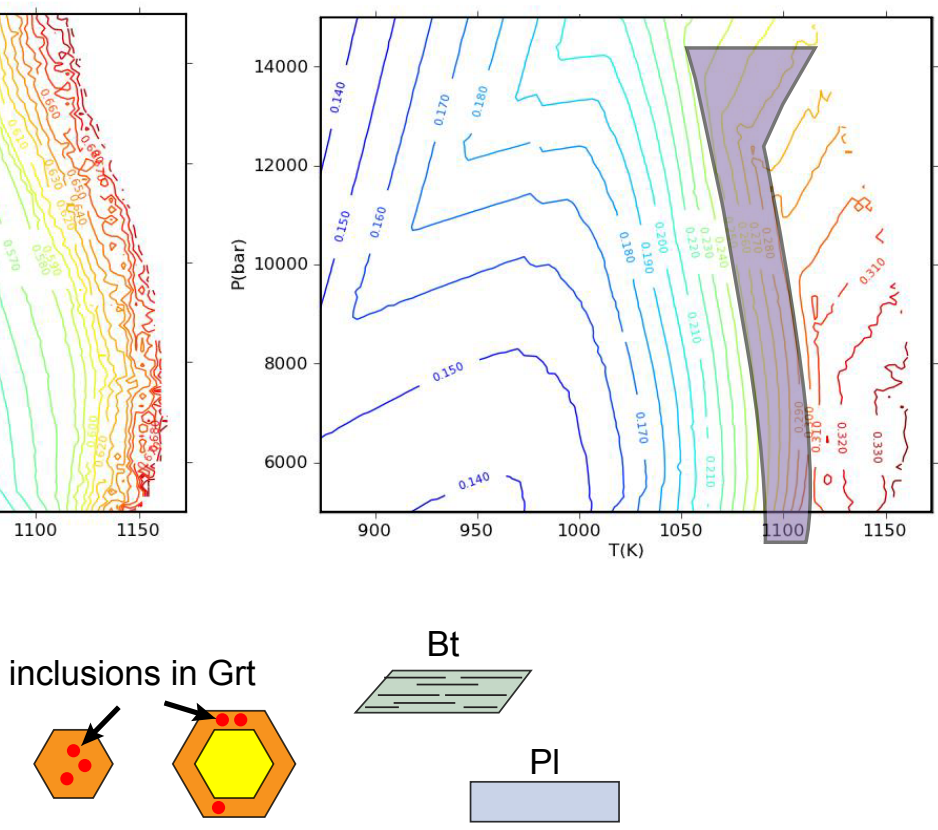

Figure 10 (Supplementary Material) 


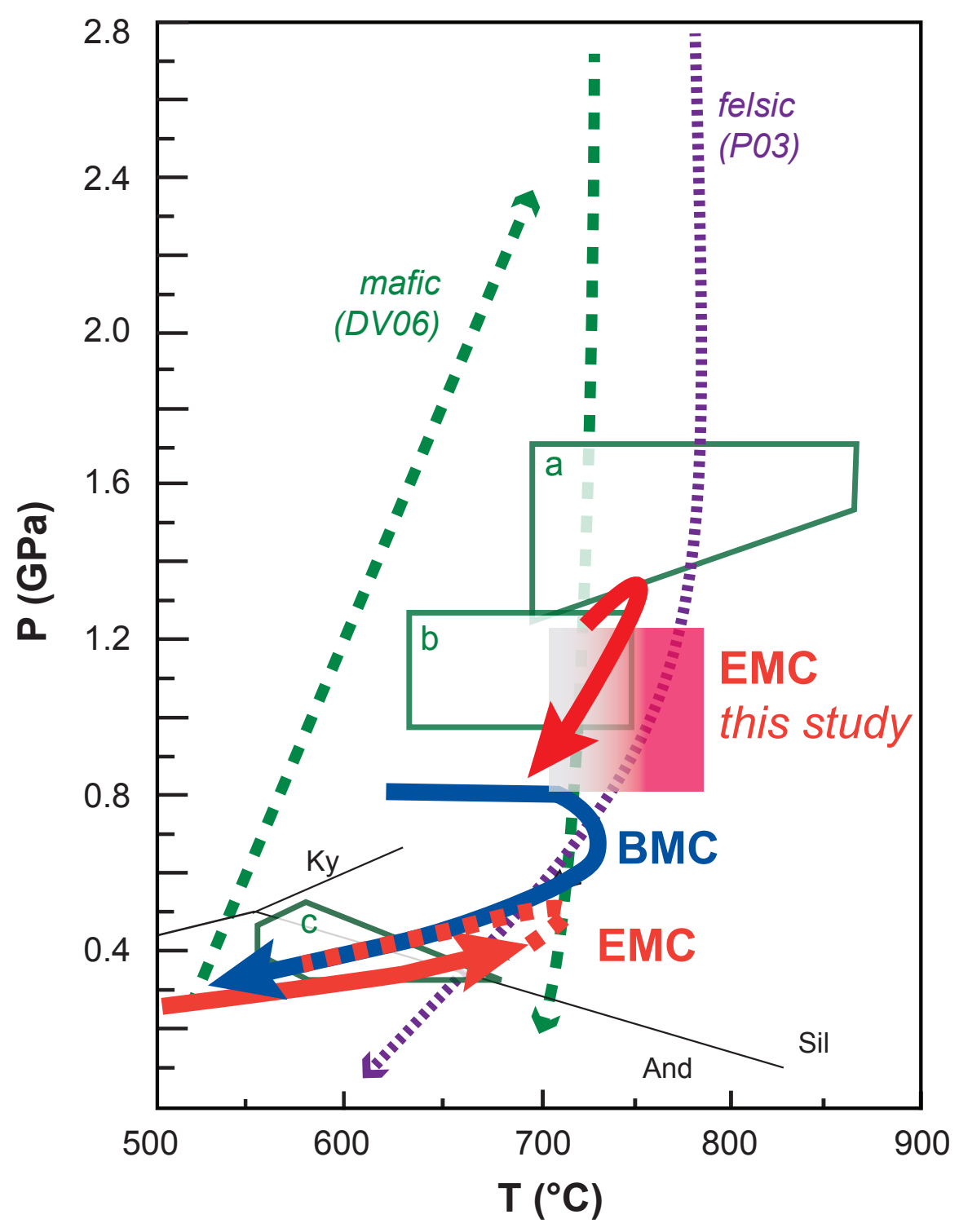

Figure 11 


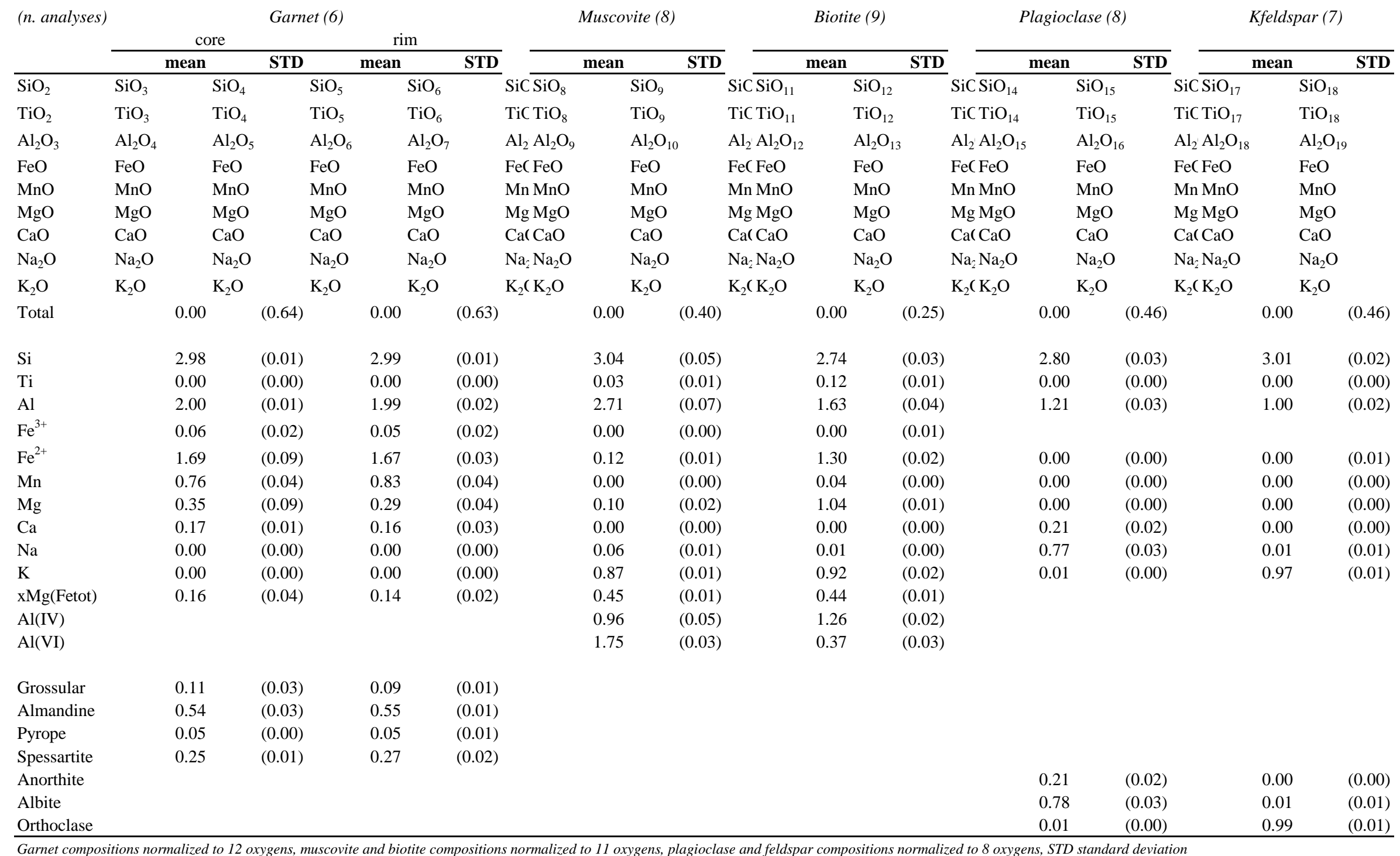




\begin{tabular}{llccc}
$\#$ & matrix & $\mathbf{T}\left({ }^{\circ} \mathbf{C}\right)$ & $\mathbf{P}(\mathbf{G P a})$ & time (hrs) \\
\hline ANT7 & $\mathrm{CaCO}_{3}$ & 740 & 0.8 & 46 \\
ANT9 & $\mathrm{CaCO}_{3}$ and $\mathrm{SiO}_{2}$ & 760 & 1.0 & 48 \\
ANT8 & $\mathrm{SiO}_{2}$ & 780 & 0.8 & 68 \\
ANT10 & $\mathrm{SiO}_{2}$ & 780 & 1.0 & 67 \\
ANT5 & $\mathrm{CaCO}_{3}$ & 810 & 0.8 & 23 \\
ANT3 & $\mathrm{CaCO}_{3}$ & 850 & 0.8 & 22 \\
ANT4 & $\mathrm{CaCO}_{3}$ & 900 & 0.8 & 21 \\
\hline
\end{tabular}




\begin{tabular}{|c|c|c|c|c|c|c|c|c|c|c|c|c|}
\hline Temp. (No. Analyses) & $\begin{array}{r}\mathbf{7 4 0}^{\circ} \mathrm{C} \\
\text { mean }\end{array}$ & $\begin{array}{r}(3) \\
{ }^{\mathrm{c}} \mathrm{STD}\end{array}$ & $\begin{array}{r}\mathbf{7 6 0}^{\circ} \mathbf{C} \\
\text { mean }\end{array}$ & $\begin{array}{l}\text { (10) } \\
\text { STD }\end{array}$ & $\begin{array}{r}\mathbf{7 8 0}^{\circ} \mathrm{C} \\
\text { mean }\end{array}$ & $\begin{array}{l}\text { (18) } \\
\text { STD }\end{array}$ & $\begin{array}{r}\mathbf{8 1 0}^{\circ} \mathbf{C} \\
\text { mean }\end{array}$ & $\begin{array}{l}\text { (14) } \\
\text { STD }\end{array}$ & $\begin{array}{r}\mathbf{8 5 0} 0^{\circ} \mathbf{C} \\
\text { mean }\end{array}$ & $\begin{array}{l}\text { (13) } \\
\text { STD }\end{array}$ & $\begin{array}{r}\mathbf{9 0 0}^{\circ} \mathbf{C} \\
\text { mean }\end{array}$ & $\begin{array}{r}\text { (9) } \\
\text { STD }\end{array}$ \\
\hline$\overline{\mathrm{SiO}_{2}}$ & 77.28 & $(0.97)$ & 74.13 & $(1.55)$ & 77.48 & $(1.00)$ & 75.52 & $(2.30)$ & 71.58 & (7.96) & 73.54 & $\overline{(5.23)}$ \\
\hline $\mathrm{TiO}_{2}$ & 0.02 & $(0.02)$ & 0.10 & $(0.11)$ & 0.10 & $(0.10)$ & 0.08 & $(0.12)$ & 0.22 & $(0.21)$ & 0.57 & $(1.30)$ \\
\hline $\mathrm{Al}_{2} \mathrm{O}_{3}$ & 14.13 & $(0.37)$ & 14.83 & $(0.63)$ & 13.22 & $(0.40)$ & 13.49 & $(1.14)$ & 15.59 & $(4.38)$ & 13.63 & $(1.20)$ \\
\hline $\mathrm{FeO}$ & 1.72 & $(0.28)$ & 1.69 & $(0.40)$ & 1.92 & $(0.23)$ & 2.59 & $(0.83)$ & 3.81 & $(2.12)$ & 3.25 & $(1.65)$ \\
\hline $\mathrm{MnO}$ & 0.63 & $(0.18)$ & 0.57 & $(0.24)$ & 0.60 & $(0.09)$ & 0.76 & $(0.25)$ & 0.75 & $(0.34)$ & 0.85 & $(0.28)$ \\
\hline $\mathrm{MgO}$ & 0.12 & $(0.06)$ & 0.11 & $(0.05)$ & 0.19 & $(0.14)$ & 0.20 & $(0.10)$ & 0.64 & $(0.66)$ & 0.21 & $(0.12)$ \\
\hline $\mathrm{CaO}$ & 0.86 & $(0.26)$ & 2.18 & $(1.16)$ & 1.24 & $(0.71)$ & 1.29 & $(0.59)$ & 1.50 & $(0.91)$ & 2.44 & (1.99) \\
\hline $\mathrm{Na}_{2} \mathrm{O}$ & 2.75 & $(0.74)$ & 2.22 & $(0.63)$ & 1.83 & $(0.35)$ & 2.18 & $(0.47)$ & 1.90 & $(1.25)$ & 2.00 & (1.17) \\
\hline $\mathrm{K}_{2} \mathrm{O}$ & 2.48 & $(0.70)$ & 4.15 & $(0.40)$ & 3.42 & $(0.54)$ & 3.89 & $(0.87)$ & 4.00 & (2.38) & 3.51 & (1.57) \\
\hline total & 100.00 & & 100.00 & & 100.00 & & 100.00 & & 100.00 & & 100.00 & \\
\hline${ }^{a}$ total $_{\text {EMPA }}$ & 85.70 & $(0.81)$ & 87.86 & $(2.20)$ & 88.97 & (1.10) & 90.06 & (1.60) & 86.53 & (1.33) & 89.29 & (2.14) \\
\hline${ }^{\mathrm{b}} \mathrm{H}_{2} \mathrm{O}$ (diff) & 14.30 & $(0.99)$ & 12.14 & $(1.87)$ & 11.03 & (1.18) & 9.94 & (1.71) & 13.47 & $(5.81)$ & 10.71 & $(2.25)$ \\
\hline ASI & 1.61 & $(0.04)$ & 1.27 & $(0.26)$ & 1.50 & $(0.17)$ & 1.35 & $(0.21)$ & 1.59 & $(0.51)$ & 1.33 & $(0.42)$ \\
\hline AI & 0.07 & $(0.00)$ & 0.07 & $(0.02)$ & 0.06 & $(0.01)$ & 0.06 & $(0.01)$ & 0.08 & $(0.04)$ & 0.06 & $(0.01)$ \\
\hline MALI & 4.38 & $(0.59)$ & 4.19 & $(1.46)$ & 4.01 & $(0.98)$ & 4.79 & $(0.86)$ & 4.40 & $(2.56)$ & 3.07 & $(1.55)$ \\
\hline
\end{tabular}

a totals from EMPA, ${ }^{b} \mathrm{H}_{2} \mathrm{O}$ by difference to $100 \%,{ }^{\mathrm{c}}$ standard deviation 


\begin{tabular}{|c|c|c|c|c|}
\hline sample & $\mathrm{H}_{2} \mathrm{O}(\mathrm{wt} \%)$ & STD & $\mathrm{CO}_{2}(\mathrm{ppm})$ & STD \\
\hline \multicolumn{5}{|c|}{ remelting $\mathrm{T}=780^{\circ} \mathrm{C} ;$ mean $\mathrm{SiO}_{2}=68.27 \mathrm{wt} . \%$} \\
\hline ANT8_1_1 & 6.66 & $(0.09)$ & 774.39 & $(19.19)$ \\
\hline ANT8_1_2 & 4.90 & $(0.06)$ & 541.17 & $(19.04)$ \\
\hline ANT8_1_3 & 4.22 & $(0.05)$ & 2019.91 & $(39.55)$ \\
\hline ANT8_1_4 & 6.52 & $(0.09)$ & 1878.96 & $(36.74)$ \\
\hline ANT8_1_5 & 6.48 & $(0.09)$ & 1648.30 & $(31.55)$ \\
\hline ANT8_1_6 & 6.21 & $(0.08)$ & 680.84 & $(16.56)$ \\
\hline ANT8_1_7 & 6.21 & $(0.08)$ & 496.32 & $(17.25)$ \\
\hline mean & 5.89 & $(0.94)$ & 1148.56 & $(670.27)$ \\
\hline ANT8_2_1 & 5.52 & $(0.07)$ & 939.69 & (19.50) \\
\hline ANT8_2_2 & 5.52 & $(0.07)$ & 1148.56 & (22.02) \\
\hline ANT8_2_3 & 4.01 & $(0.05)$ & 849.99 & (18.09) \\
\hline ANT8_2_4 & 4.11 & $(0.05)$ & 1750.82 & (34.39) \\
\hline ANT8_2_3 & 5.63 & $(0.07)$ & 1725.19 & (37.19) \\
\hline mean & 4.96 & $(0.82)$ & 1282.85 & $(429.48)$ \\
\hline ANT10_1_1 & 4.83 & $(0.06)$ & 1128.05 & (22.70) \\
\hline ANT10_1_2 & 2.98 & $(0.05)$ & 710.32 & $(17.85)$ \\
\hline ANT10_1_3 & 4.80 & $(0.05)$ & 624.46 & (17.12) \\
\hline mean & 4.20 & $(1.06)$ & 820.94 & $(269.41)$ \\
\hline ANT10_2_1 & 5.73 & $(0.07)$ & 916.62 & (20.10) \\
\hline ANT10_2_2 & 5.28 & $(0.06)$ & 1661.12 & $(34.52)$ \\
\hline mean & 5.51 & $(0.32)$ & 1288.87 & $(526.44)$ \\
\hline \multicolumn{5}{|c|}{ remelting $T=760^{\circ} \mathrm{C}$; mean $\mathrm{SiO}_{2}=65.02 \mathrm{wt} . \%$} \\
\hline ANT9_1_1 & 2.47 & $(0.05)$ & 265.23 & $(18.28)$ \\
\hline ANT9_1_2 & 2.40 & $(0.05)$ & 209.09 & $(18.51)$ \\
\hline ANT9_1_3 & 6.44 & $(0.09)$ & 443.40 & $(17.03)$ \\
\hline ANT9_1_4 & 7.88 & $(0.13)$ & 512.97 & $(17.69)$ \\
\hline ANT9_1_5 & 5.49 & $(0.07)$ & 588.63 & $(18.11)$ \\
\hline ANT9_1_6 & 4.11 & $(0.05)$ & 613.04 & $(18.78)$ \\
\hline ANT9_1_7 & 5.72 & $(0.08)$ & 188.34 & (19.18) \\
\hline mean & 4.93 & $(2.04)$ & 402.96 & $(180.26)$ \\
\hline ANT9_2_1 & 4.21 & $(0.05)$ & 770.47 & (19.33) \\
\hline ANT9_2_2 & 2.50 & $(0.05)$ & 489.78 & (16.15) \\
\hline ANT9_2_3 & 4.87 & $(0.06)$ & 443.40 & (17.42) \\
\hline mean & 3.86 & $(1.22)$ & 567.89 & (176.97) \\
\hline ANT9_3_1 & 2.71 & $(0.05)$ & 296.96 & (17.88) \\
\hline ANT9_3_2 & 2.61 & $(0.05)$ & 228.61 & (18.55) \\
\hline ANT9_3_3 & 5.03 & $(0.06)$ & 248.14 & (19.26) \\
\hline mean & 3.45 & $(1.37)$ & 257.90 & $(35.20)$ \\
\hline
\end{tabular}

STD = standard deviation 